\title{
Assessments of marketing and management practices of Appalachian hardwood sawmills
}

\author{
David Bradley Summerfield \\ West Virginia University
}

Follow this and additional works at: https://researchrepository.wvu.edu/etd

\section{Recommended Citation}

Summerfield, David Bradley, "Assessments of marketing and management practices of Appalachian hardwood sawmills" (2011). Graduate Theses, Dissertations, and Problem Reports. 4800.

https://researchrepository.wvu.edu/etd/4800

This Thesis is protected by copyright and/or related rights. It has been brought to you by the The Research Repository @ WVU with permission from the rights-holder(s). You are free to use this Thesis in any way that is permitted by the copyright and related rights legislation that applies to your use. For other uses you must obtain permission from the rights-holder(s) directly, unless additional rights are indicated by a Creative Commons license in the record and/ or on the work itself. This Thesis has been accepted for inclusion in WVU Graduate Theses, Dissertations, and Problem Reports collection by an authorized administrator of The Research Repository @ WVU. For more information, please contact researchrepository@mail.wvu.edu. 
APPALACHIAN HARDWOOD SAWMILLS

\author{
David Bradley Summerfield
}

Thesis submitted to the

Davis College of Agriculture, Natural Resources, and Design

at West Virginia University

in partial fulfillment of the requirements

for the degree of

\author{
Master of Science \\ in \\ Forestry
}
Jingxin Wang, Ph.D., Chair
Ben Spong, Ph.D.
David DeVallance, Ph.D.

Bhaskaran Gopalakrishnan, Ph.D.

Division of Forestry and Natural Resources

\title{
Morgantown, West Virginia 2011
}

Keywords: Appalachian hardwood, sawmill, primary processing, marketing strategies, energy audits, energy efficiency, economic downturn 


\title{
ABSTRACT \\ ASSESSMENTS OF MANAGEMENT AND MARKETING PRACTICES OF APPALACHIAN HARDWOOD SAWMILLS
}

\author{
David Bradley Summerfield
}

A mail survey was conducted in the fall of 2010 to investigate the profitability aspects of the Appalachian hardwood sawmills. Specifically, the survey focused on changes in production, employment, marketing, export and energy efficiency practices between 2008 and 2010. The majority of the respondents used circle-saw headrigs (57\%) and the remaining (43\%) used bandsaw headrigs. The results indicated that employees in the Appalachian region had decreased by 28.88 percent while production decreased by 26 percent. Among responding sawmills, the number of employees decreased significantly since the economic downturn $(p=0.0267)$ although four survey respondents reported hiring new employees. The most employment opportunities were lost in companies that had been in business either for a short or medium time period (less than fifty years). Meanwhile, yearly operating hours decreased by 9 percent per mill. The changes in the annual operating hours were significantly different among the surveyed sawmills $(p=0.0005)$. Statistical analysis results indicated that the number of employees was significantly different among states, production levels, interactions between state and production level and years in business. Likewise, the interactions between state and production level and between production level and years in business also significantly affected the weekly production. During the downturn employees decreased from 42 to 30 per mill, annual operating hours decreased from 2,336 to 2,132 hours, and weekly lumber production decreased from 196,792 to 145,610 thousand board feet (MBF) per week per mill. In 2010, log inventory at sawmills averaged 6 weeks. Sixty-four percent of the respondents stated that their log inventory decreased, 28 percent of the surveyed sawmills kept the same inventory level, and the rest increased log inventory. The average chips and sawdust production in 2010 was 257 and 152 tons per week, respectively, in sawmills of high production level, while the numbers changed to 91 and 55 tons per week in medium production level sawmills, and 48 and 18 tons per week, respectively, in low production level sawmills. Wood residue was most commonly used for animal bedding \& litter (37\%), followed by boiler fuel, and pulp \& paper. Oak was the highest profit species, which accounted for 38.1 percent of the surveyed, sawmills, followed by hard maple (19\%), ash (17\%), and walnut (14\%). Yellow-poplar was the lowest profit species (36\%), followed by cherry (26\%) and soft maple (17\%). Sixty-six percent of sawmills responded that they have made marketing changes since the economic downturn, while forty-six percent of the respondents exported products in 2010 .

The energy consumption and energy efficiency were also examined for Appalachian hardwood sawmills using a mail survey and onsite energy audits. Only 19 percent of the respondents planned on making energy efficient upgrades in 2010. About 38, 45, and 17 percent of the respondents ran electric motors at 80-90 percent, 91-94 percent, and 95 percent or more efficiency, respectively. About 40 and 50 percent of the responding sawmills used conventional 
air compressors and high efficiency screw-drive air compressors, respectively. The other 10 percent of the respondents used both types of air compressors. The electrical consumption per week per mill in 2010 averaged 107,007 kWh with an average bill of $\$ 9,278$ per month while the average natural gas consumption was 1,125 thousand cubic feet (MCF) per month per mill with an average bill of $\$ 5,703$. A dry kiln owner own 5 dry kilns in average with an average capacity of 4,521 MBF per year per mill. The electricity per month per mill used for kilns was 64,125 $\mathrm{kWh}$ with an average electricity bill of $\$ 5,560$. Energy audits of 17 sawmills in West Virginia indicated that the average electric consumption of lumber production was $161 \mathrm{kWh} / \mathrm{MBF}$ and the marginal cost averaged $\$ 17.87 / \mathrm{MMBtu}(\not 6.10 / \mathrm{kWh})$. The average processing cost was $\$ 10.04 / \mathrm{MBF}$ ranging from $\$ 0.81 / \mathrm{MBF}$ to $\$ 22.01 / \mathrm{MBF}$. The average energy savings could be 916 MMBtu or $275,110 \mathrm{kWh}$ per mill while the average carbon dioxide emissions could be reduced by $587,045 \mathrm{lbs}$ per month per mill. Implementation cost for assessment recommendations at sawmills ranged from $\$ 0$ to $\$ 100,000$ with an average of $\$ 18,633$. Average energy savings per year could be up to 15 percent through the implementation of the recommended changes. 


\section{Acknowledgements}

I would like to thank Dr. Jingxin Wang, my major professor and advisor, for the funding to complete my research. I would also like to thank him for the advice on my project, and guidance throughout my career at WVU. I would like to extend a special thanks to Dr. Joseph McNeel for funding during my first semester of graduate school. I would also like to thank Drs. Ben Spong, David DeVallance, and Bhaskaran Gopalakrishnan for their guidance throughout the survey design process and writing of my thesis. I thank Dr. Bhaskaran Gopalakrishnan and Mr. Shawn Grushecky for providing energy audits data of sawmills in West Virginia. Specifically, I am grateful to my fellow graduate, Dr. Wenshu Lin, for his unselfish assistance in data collection, analysis, and thesis review. 


\section{TABLE OF CONTENTS}

Table of Contents

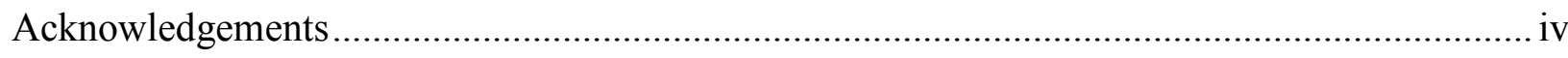

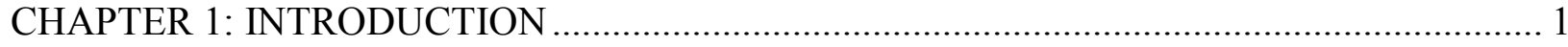

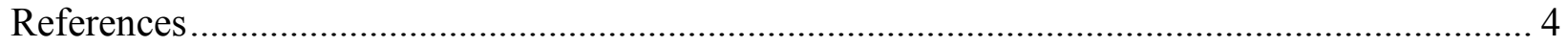

CHAPTER 2: ASSESSMENTS OF THE IMPACTS OF ECONOMIC DOWNTURN ON APPALACHIAN HARDWOOD SAWMILLS ........................................................................ 5

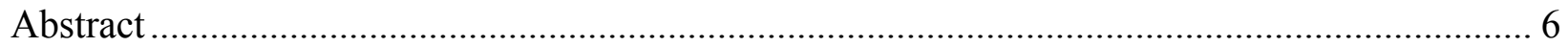

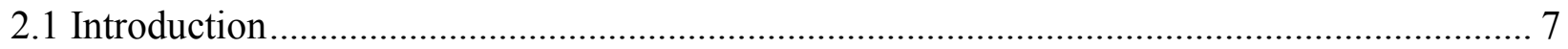

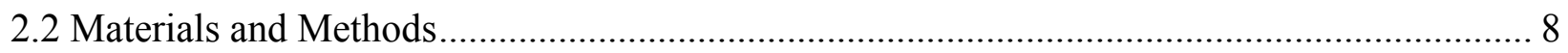

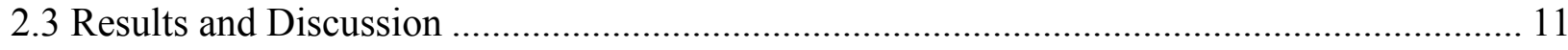

2.3.1 Changes in employment, operating hours, and production ................................... 11

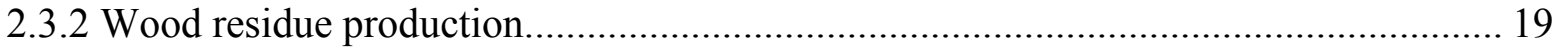

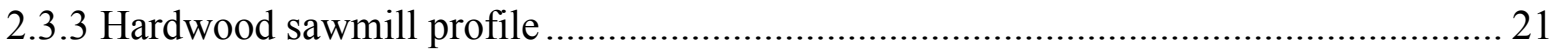

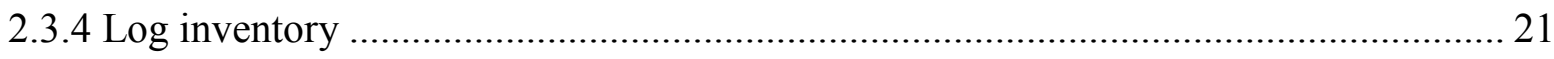

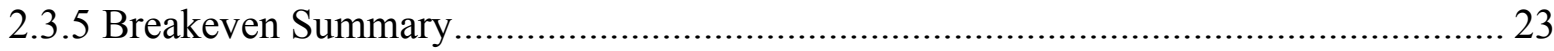

2.3.6 Market distribution and strategies ............................................................. 25

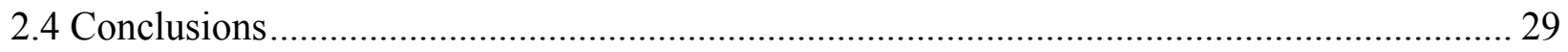

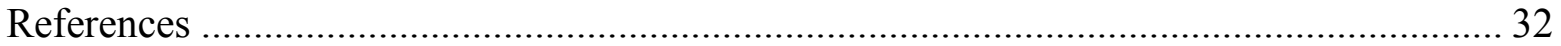

CHAPTER 3: ENERGY CONSUMPTION AND EFFICIENCY OF HARDWOOD SAWMILLS IN THE APPALACHIAN REGION ............................................................. 35

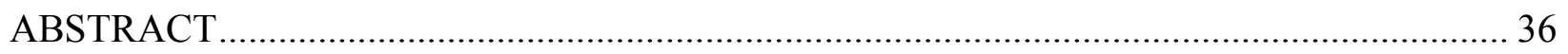

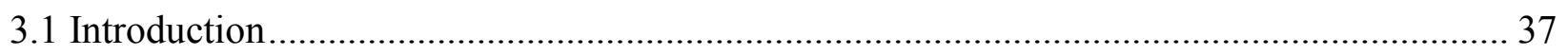

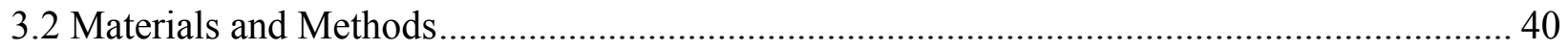

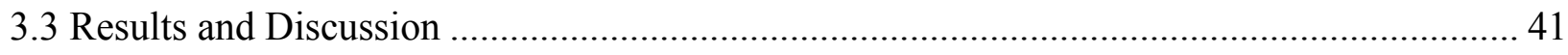

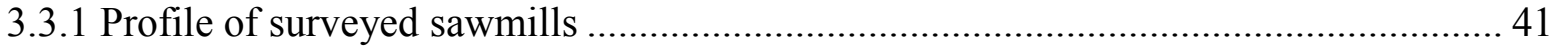

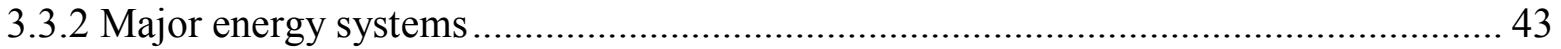

3.3.3 Energy audit conservation opportunities ........................................................... 46

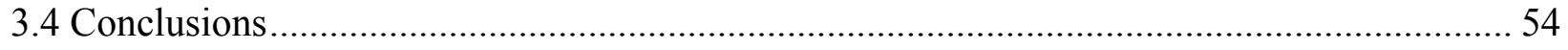




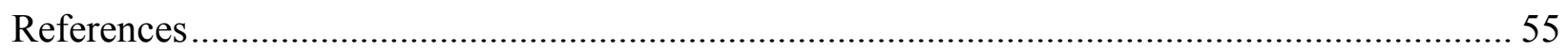

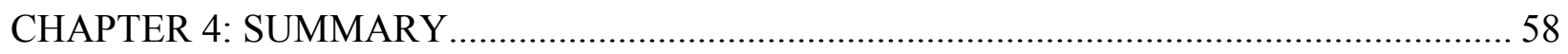

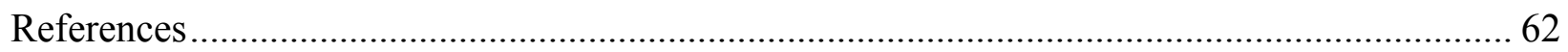




\section{LIST OF TABLES}

Table 2.1 Employment changes of sawmills before and after downturn.................................12

Table 2.2 Hours, employees and production changes before and after downturn .......................13

Table 2.3 Yearly operating hour changes of sawmills before and after downturn ......................16

Table 2.4 Weekly production changes of sawmills before and after downturn..........................17

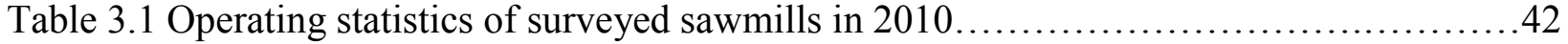

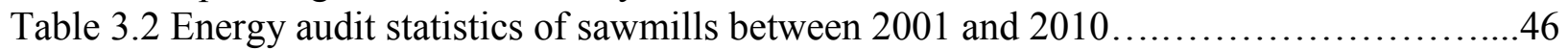

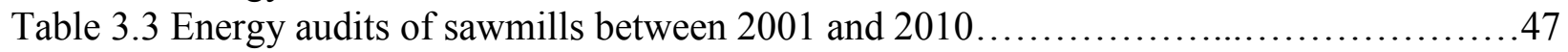




\section{LIST OF FIGURES}

Figure 2.1 Wood residue production by business years, production level and state..............19

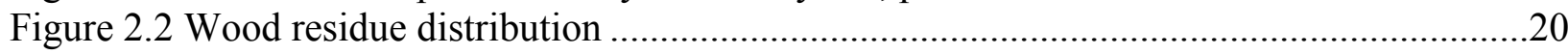

Figure 2.3 Log inventory in sawmills for different business years, production level, and states..22

Figure 2.4 Break even and lose money by business years, production level and state ................24

Figure 2.5 Wood products distribution by product type .....................................................25

Figure 2.6 (a) lowest profit margin species, (b) Highest profit margin species..................27

Figure 2.7 Wood products exporting countries distribution .................................................28

Figure 3.1 Energy efficiency recommendations issued to sawmills.........................48

Figure 3.2 Average energy usage per MBF of lumber production by year.....................50

Figure 3.3 (a) Total energy cost in \$/MBF based on production, (b) Energy consumed \$/MBF (excludes demand rate and taxes), (c) Energy usage (kWh/MBF) ..........................51

Figure 3.4 Average total cost per MBF of lumber production based on audit year.................52

Figure 3.5 Average energy conserved if all recommendations are implemented..................53 


\section{CHAPTER 1: INTRODUCTION}

Extending 235,000 square miles from New York to Georgia and from Virginia to Missouri, the Appalachian region holds vast expanses of high quality hardwood timber. The region harbors the most extensive concentration of deciduous hardwoods in the world and represents a very rich and complex mixture of tree species and sites (Hicks 1998). The Appalachian region supplies 68 percent of the eastern hardwood sawtimber in the US. In addition, more than 70 percent of the hardwood lumber produced in the US is manufactured at sawmills in this region (Luppold 1995).

Appalachia's valuable resources need to be processed in a manner that maximizes profits for business owners, while utilizing sustainable forestry practices. Many mills have been struggling to make a profit since the economic downturn that started in late 2008 . The endless struggle to turn a profit comes partially from the inability to adapt business models to current market conditions. With many sawmills using the same outdated management and marketing practices, businesses are failing as margins get increasingly slim. The current economic downturn has dramatically decreased profit margins in the past couple of years for some previous high profit margin lumber such as black cherry (Hardwood Market Report 2007, 2010). Decreasing lumber prices, rising energy prices and high fuel surcharges since 2008 have spelled a disaster for many sawmill owners in the Appalachian region.

Mill owners and managers must become more market oriented in order to adequately meet the needs of changing market conditions. The inability to adapt new marketing approaches to current economic conditions can easily put a mill out of business. Historically speaking, sawmills have been slow to adapt to the changing industry. Sawmills today still typically tend to 
be a low technology segment in the manufacturing industry (Bowe et al. 2001). This slow adaptation still applies today since a lot of sawmills are struggling because of smaller profit margins.

Utility bills can become burdensome for sawmills, especially if energy efficiency is completely ignored. Energy consumption in a hardwood sawmill typically ranges between one and ten percent of the total operating costs (Mardikar 2007). Energy costs have risen drastically in the past decade thus more attention needs to be given to energy conservation. The price of natural gas for industrial use has more than doubled from 1997 to 2007 while electric rate has increased 40\% during the same period (US Department of Energy 2008). Typically, three to four percent of production cost stems from utility costs (Bond 2008). Utility savings on this three to four percent could add some substantial money to the bottom line.

Five percent of the total energy in the U.S, is used by sawmills, both hardwood and softwood (Bond 2008). Sawmills will typically have electric motors rebuilt after they fail. However, the motor loses efficiency each time after it is rebuilt. This efficiency loss could be substantial after the motor has been rebuilt for several times (Mardikar 2007). The lifetime energy cost to run a continuous-duty motor is 10 to 20 times higher than the original motor purchase price. Thus, energy-efficient motors can play a major role in reducing facility operating costs (California Energy Commission 2000). Energy efficiency improvement can help sawmills operators to make their business more profitable while reducing operating costs.

The forest industry plays a vital role in the economy of Appalachia. The global economic downturn and the current decline of the housing market are throwing a relentless string of problems at the regional hardwood sawmills. Increased energy costs make it difficult for 
Appalachian sawmills to operate profitably. Therefore, the objectives of this study were to (1) assess the impacts of the economic downturn on hardwood sawmills in the Appalachian region, including the changes in operational hours, employment, production volume, wood residue production, log inventory and marketing and exporting practices before and after the economic downturn; and (2) examine the energy consumption and efficiency of the Appalachian sawmills, specifically, in West Virginia, including energy consumption, recommendations to sawmills regarding effective ways of reducing both energy consumption and costs, and energy conservation opportunities. 


\section{References}

Bond, B. 2008. Sawmill \& Treating Insights: Rein in Escalating Energy Costs.http://www.palletenterprise.com/articledatabase/view.asp?articleID=2648. Accessed May 1, 2011.

Bowe, SA., RL. Smith, and P.A. Araman. 2001. A national profile of the U.S. hardwood sawmill industry. Forest Prod. J. 51(10):25-31.

California Energy Commission. Energy efficient motors. 2000, November 14. Retrieved from http://www.energy.ca.gov/process/pubs/motors.pdf

Hardwood Market Report. Hardwood Market Report, 2007. Lumber News Letter, vol. LXXXV. Hardwood Market Report, Memphis, TN.

Hardwood Market Report. Hardwood Market Report, 2010. Lumber News Letter, vol. LXXXVIII. Hardwood Market Report, Memphis, TN.

Hicks, R.R. 1998. Ecology and management of central hardwood forests. John Wiley \& Sonc, Inc.

Luppold, W.G. 1995. Effect of the hardwood resource on the sawmill industry in the central and Appalachian regions. In: Gottschalk, Kurt W., Fosbroke, Sandra L. C., ed. Proceedings, 10th Central Hardwood Forest Conference, Morgantown, WV. Gen. Tech. Rep: 481-487.

Mardikar, Y. 2007. Establishing baseline electrical energy consumption in wood processing sawmills. Morgantown, WV

U.S. Department of Energy. 2008. http://www1.eere.energy.gov/industry/saveenergynow/index.html. Accessed May 1, 2011 
CHAPTER 2: ASSESSMENTS OF THE IMPACTS OF ECONOMIC DOWNTURN ON APPALACHIAN HARDWOOD SAWMILLS ${ }^{1}$

\footnotetext{
${ }^{1}$ To be submitted to Forest Products Journal
} 


\begin{abstract}
A mail survey of 776 sawmills was conducted in the fall of 2010 to investigate the impacts of economic downturn on sawmill production, employment, and marketing and exporting practices in the Appalachian region. The results from the mail survey found that the average employee numbers per mill decreased by 29 percent from 42 to 30, the average annual operation hours decreased by 9 percent from 2336 to 2132, and the average weekly lumber production decreased by 26 percent from 196,792 to 145,610 compared to 2008 . The statistical analysis results indicated that the variables of states, production level, interaction between states and production level, interaction between states and business years, and interaction between production level and business years had statistically significant effects on the variation in the number of employees. The operating hours per year were significantly different among the states. While the interaction between state and production level, and interaction between production level and business years significantly affected the weekly production. In 2010, the average log inventory across the industry was six weeks. Average residue production in the surveyed sawmills was 139 tons for chips and 81 tons for sawdust per week. More than half of the responding sawmills (67\%) have changed their marketing strategies since the turbulent economic times. Results also showed that 46 percent of the respondents exported their wood products.
\end{abstract}

Keywords: Appalachian hardwood, sawmilling, primary processing, marketing, management. 


\subsection{Introduction}

The Appalachian region which contains a diverse and valuable hardwood timber resource is one of the most important hardwood lumber producing regions in the U.S. supplying 68 percent of the eastern hardwood sawtimber. In addition, more than 70 percent of the hardwood lumber produced in the U.S. is manufactured at sawmills located in this region. (Luppold 1995)

Hardwood sawmills are the foundation of the Appalachian hardwood industry. The production capacity of hardwood sawmills in the Appalachian region ranged from less than 100,000 board feet to more than 50 million board feet (MMBF) per year (Luppold 1995, Luppold et al. 2000). Since 2000, the production of hardwood lumber in the U.S. has fallen 25 percent (Parhizkar et al. 2009). The eastern hardwood lumber production declined by 23 percent between 1997 and 2008, and the hardwood production in the Appalachian hardwood region has declined by more than 40 percent (Luppold 2009, Wang et al. 2010).

The global economic downturn and the decline of the housing market are throwing a relentless string of problems at the hardwood sawmills that make up much of the nation's hardwood lumber industry. Especially in 2008-2009, the United States financial and economic crisis escalated and spread globally, causing devastating effects on the hardwood products industry. The crisis is the main driver for the decline of wood products demand - housing reducing from 2.2 million units in 2005 to below 500,000 units in 2009 (UNECE 2009). The current US housing market collapse has caused half of the North American sawmills to temporarily curtail production or close in order to accommodate much lower demand. The economic downturn has caused many hardwood sawmills to change, and have eroded the understanding of the hardwood sawmill industry in the Appalachian region. 
To survive in the current turbulent economic conditions, hardwood sawmills also need to change their management and marketing strategies to locate new markets where their products are welcomed and demanded. One of the most important marketing aspects for sawmills is to diversify marketing strategies and to export internationally. Many Appalachian sawmills are unsure of exporting products for fear of not getting paid and the high cost of transportation (Wang et al. 2010). These two issues prove to be entry barriers for many Appalachian sawmills. However, the increase in demand for hardwood lumber by foreign countries may tempt more sawmills to start exporting lumber overseas (Smith et al. 2004). The globalization of the furniture market has created increased exports for furniture manufacturing in recent years (Holmes et al. 2010). Mill managers must become more market oriented in order to adequately meet the needs of changing market conditions.

To better serve the hardwood lumber industry in the region, it is necessary to study the hardwood sawmills and examine their management efficiency and marketing strategies.

Therefore, this study determined the impacts of economic downturn on hardwood sawmills in the Appalachian hardwood region. Specifically, the objectives of this study were to assess the impacts of economic downturn on the Appalachian sawmills including the changes in operation hours, employment, and production volume, wood residue production, log inventory, marketing and exporting practices before and after the economic downturn for the Appalachian hardwood sawmill industry.

\subsection{Materials and Methods}

The survey was designed using the Dillman's tailored design method due to the large number of questions involved (Dillman 2000). Each mail survey contained a cover letter, a questionnaire, and a postage paid return envelope. The cover letter explained the nature and 
importance of the survey and stressed firm anonymity for any information provided. The questionnaires were designed to gather information on the hardwood sawmill industry before and after the economic downturn in the Appalachian region. The economic downturn started in December of 2007 and took a drastic downturn in September 2008 (Hudlend 2011). A total of fifty-nine questions were designed, which covered general company information, processing and production, energy consumption and efficiency, management strategies, and marketing and export strategies. Twenty-three of the questions were multiple-choice. Twenty-four questions were filling in the blank, and twelve questions were short answer. A pretest questionnaire was sent to 5 individuals in West Virginia in summer of 2010, a few changes were made as a result of the pretest. The mailing list of hardwood firms was obtained from the National Hardwood Lumber Association (NHLA), the Appalachian Regional Commission (ARC), and other state agencies. Approximately 776 firms in the Appalachian region were selected as the sample population: 165 in West Virginia, 307 in Pennsylvania, 151 in Ohio, 73 in New York, 36 in Maryland, 12 in North Carolina, and 32 in other states. In the summer of 2010, one formal mail survey was conducted to collect data from U.S. hardwood firms in the Appalachian region. All non-respondents from the first survey were sent a second questionnaire in the fall of 2010.

Returned surveys were examined for completeness and usability, and were then entered into Excel spreadsheets and analyzed using the Statistical Analysis System (SAS). The responding mills were first grouped by state (WV, PA, OH, NY, Others) in which the mills were operated. Mills were also categorized by operation years: long-term operation (more than 50 years), medium-term operation ( 25 to 50 years), and short-term operation ( 25 or fewer years). Mills were categorized based on their production in board feet $(\mathrm{BF})$ per week: high production 
(more than $200000 \mathrm{BF}$ ), medium production (40000 to $200000 \mathrm{BF}$ ), and low production (less than $40000 \mathrm{BF})$.

A general linear model (GLM) was used to analyze the differences in the operating hours, number of employees, and lumber production (board feet per week) before and after the economic downturn in 2008. The independent variables included states, production level, mill's business years, and the interactions terms among these variables. The GLM for analyzing the difference can be expressed as:

$$
\operatorname{Diff}_{i j k l}=\mu+S T_{i}+P L_{j}+\text { Year }_{k}+S T_{i} * P L_{j}+S T_{i} * \text { Year }_{j}+P L_{j} * \text { Year }_{k}+\varepsilon_{i j k l}
$$

$i=1,2, \ldots 5$

$j=1,2,3$

$k=1,2,3$

Where, Diff ${ }_{i j k l}=$ the $l t h$ observation of the difference of operation hours, or the number of employees or lumber production (board feet per week) before and after the economic downturn, $\mu=$ the mean of each response variable, $S T_{i}=$ the effect of the ith states, $P L_{j}=$ the effect of the $j$ th production level, Year $_{k}=$ the effect of the $k t h$ number of business years, $\varepsilon_{i j k l}=$ an error component that represents uncontrolled variability, and 
$l=$ the number of observations within each treatment.

\subsection{Results and Discussion}

A total of 238 responses were received, of which 58 surveys were usable. They included 21 from Pennsylvania, 16 from West Virginia, 8 from Ohio, 6 from New York, and 7 from other states. Because of the relatively small number of mills reporting from Connecticut, Maryland, Missouri, and South Carolina, data for those states were grouped together as other states. One hundred and twenty three surveys were returned due to undeliverable or address change and other 57 returned replies included those from firms that returned the forms blank or with insufficient information, or those firms were no longer in the hardwood sawmill business. Thus, the adjusted response rate of this survey was 9.9 percent. The adjusted response rate was calculated by dividing the number of returned and completed questionnaires by the total number of mailed survey after subtracting unusable questionnaires. The response rate seems low. This can be attributed to the mailing list included primary and secondary wood products manufacturers, however, the survey focused on the primary processors.

\subsubsection{Changes in employment, operating hours, and production (1) Changes in employment}

Currently, some sawmills are going out of business and most of the remaining mills are curtailing production in order to cater to the lower market demand. This decreased production is resulting in loss of employment opportunities throughout the whole hardwood industry. The changes in employment were analyzed before and after the economic downturn. In 2008, the number of employees averaged 42 per mill ranging from 1 to 200 . However, the average number of employees per sawmill dropped to 30 in 2010, decreasing by 29 percent compared to 2008 (Table 2.1). 
Table 2.1.- Employment changes of sawmills before and after downturn.

\begin{tabular}{|c|c|c|c|c|c|c|}
\hline \multicolumn{7}{|c|}{ \# of employees } \\
\hline & \multicolumn{3}{|c|}{ Before Downturn } & \multicolumn{3}{|c|}{ After Downturn } \\
\hline & Mean & Min & Max & Mean & Min & Max \\
\hline \multicolumn{7}{|c|}{ State } \\
\hline West Virginia & 52 & 2 & 400 & 27 & 0 & 135 \\
\hline Pennsylvania & 23 & 1 & 80 & 16 & 1 & 60 \\
\hline Ohio & 35 & 5 & 185 & 33 & 4 & 170 \\
\hline New York & 80 & 15 & 200 & 63 & 15 & 200 \\
\hline Others & 57 & 32 & 138 & 45 & 28 & 84 \\
\hline Industry Wide & 42 & 1 & 400 & 30 & 0 & 200 \\
\hline \multicolumn{7}{|c|}{ Years in Business } \\
\hline Long & 32 & 4 & 53 & 26 & 4 & 50 \\
\hline Medium & 58 & 1 & 400 & 39 & 1 & 200 \\
\hline Short & 19 & 1 & 67 & 15 & 1 & 53 \\
\hline \multicolumn{7}{|c|}{ Production } \\
\hline Medium & 29 & 5 & 105 & 21 & 0 & 50 \\
\hline Large & 97 & 27 & 400 & 73 & 27 & 200 \\
\hline
\end{tabular}

The hardwood sawmills in West Virginia experienced a sharp drop in the number of employees post economic downturn. Employee changes ranged from 0 (no change) to 100 percent (total layoff, firm close). The mean number of employees reduced by 24.9 percent compared to 2008. The number of sawmill employees in Pennsylvania decreased by an average of 7.16 employees. A t-test was used to determine the difference in the number of employees. There was a maximum of 21 employees' difference and minimum of no change. It was noted that the changes in employee average numbers were significant $(p=0.0006)$ among sawmills in Pennsylvania. The change in sawmill employees in Ohio was extremely small only 2 less employees compared to 2008. The average number of employees in New York sawmills 
decreased by 16.83 employees with a maximum change of 85 workers and a minimum change of 2 workers. The results indicated that the number of employees was dramatically changed in sawmills in West Virginia, Pennsylvania and New York.

There were only four sawmills employed new employees from 2008 to 2010 in this survey. However, the total number of new employees is still relatively small. When further looking at those sawmills, we found that these sawmills were located in Ohio and produced pallet stock. These four respondents also stated that they have changed their marketing strategies under the tough economic times. Among responding sawmills, the number of employees changed significantly from 2008 to 2010 with a corresponding $p$-value of 0.0267 (Table 2.2).

Table 2. 2.- Hours, employees and production changes before and after downturn.

\begin{tabular}{lcccccc}
\hline Variable & T-stat. & p-value & Min & Max & $\begin{array}{c}\text { Standard } \\
\text { Deviation }\end{array}$ & $\begin{array}{c}\text { Standard } \\
\text { Error }\end{array}$ \\
& & & & & & \\
\hline Change in Hours & -3.74 & .0005 & -2000 & 0 & 393 & 55 \\
Change in Employees & -2.28 & .0267 & -265 & 2 & 38 & 5.15 \\
Change in Production & -2.32 & .0248 & -1000000 & 6650 & 163389 & 23107 \\
\hline
\end{tabular}

For those sawmills with longer years in business, the number of employees was reduced by 18.67 percent compared to 2008 . The average number of employees decreased by 32.11 percent for sawmills with years in business in the medium category while the average employee numbers declined by 24.72 percent for sawmills in short category of years in business. The results indicated that more employment opportunities were lost in sawmills in both short and medium categories of years in business. 
Sawmills in the low production category showed a 27 percent reduction in the number of employees.. This number changed to 29 percent and 25 percent for sawmills in medium or high production level. The results indicated that the number of employees has drastically decreased for sawmills of different production levels due to economic downturn.

The survey also asked two other questions about employees, "If you laid employees off within the past year, have you been able to hire them back?" and "Does your company have trouble finding quality workers?" All respondents laid off employees within the past year. About 41 percent of respondents stated that they did not hire back employees and 67 percent of respondents had trouble finding quality workers.

A GLM model was developed to examine how state, years in business, and sawmill production level affected the changes in the number of employees, yearly operation hours, and weekly production. The results showed that states $(\mathrm{F}=32.61 ; \mathrm{df}=4,28 ; p<0.0001)$, production level $(\mathrm{F}=40.21 ; \mathrm{df}=2,28 ; p<0.0001)$, interaction between states and production level $(\mathrm{F}=41.81$; $\mathrm{df}=5,28 ; p<0.0001)$, interaction between states and business years $(\mathrm{F}=22.7 ; \mathrm{df}=7,28 ; p<$ $0.0001)$, and interaction between production level and business years $(\mathrm{F}=43.51 ; \mathrm{df}=4,28 ; p<$ 0.0001) had statistically significant effects on the changes in the number of employees.

\section{(2) Changes in operating hours}

The changes in the annual operating hours were significantly different among the surveyed sawmills ( $p=0.0005$ ). Based on the GLM model results, it was found that states $(\mathrm{F}=4.34 ; \mathrm{DF}=4,26 ; p=0.0081)$ significantly affected the changes in annual operating hours. The sawmills in West Virginia operated an average of 505 less hours per year in 2010, a sharp decline compared to 2,583 hours in 2008 . Similarly, the change in operating hours was 
significantly different among sawmills in West Virginia $(p=0.0273)$. Pennsylvania sawmills have experienced a rather small decline in annual operating hours compared to West Virginia, which ranged from 80 hours per year to a maximum change of 672 fewer hours. The sawmills in Ohio experienced a very small change in annual operating hours since the economic downturn with an average decrease of 187 hours. Sawmills in New York also experienced a small decrease in operating hours per year with a mean value of 128 less operating hours.

For those sawmills with longer years in business, the average annual operating hours reduced by 5 percent since the economic downturn. However, the average operating hours reduced by 8 or 16 percent for sawmills with medium or shorter years in business, respectively. The results also indicated that sawmills that have been in business for a long time had more capability to deal with economic downturn and could still keep their mills running without significantly reducing their operation hours. When comparing the different sawmill sizes it was found that; sawmills with lower production level operated 7\% less hours per year, which was higher than the $6 \%$ for the sawmills with medium production level. Sawmills with high annual production level decreased operating hours by $14 \%$ (Table 2.3 ). Therefore, the economic downturn had more significant effects on sawmills with high production levels in terms of annual operation hours. 
Table 2.3.- Yearly operating hour changes of sawmills before and after downturn.

\begin{tabular}{|c|c|c|c|c|c|c|}
\hline \multicolumn{7}{|c|}{ Yearly Operating Hours } \\
\hline & \multicolumn{3}{|c|}{ Before Downturn } & \multicolumn{3}{|c|}{ After Downturn } \\
\hline & Mean & Min & Max & Mean & Min & Max \\
\hline & \multicolumn{6}{|c|}{ State } \\
\hline West Virginia & 2,583 & 1,440 & 4,032 & 2,079 & 960 & 4,032 \\
\hline Pennsylvania & 2,199 & 1,440 & 3,016 & 2,120 & 768 & 3,016 \\
\hline Ohio & 2,168 & 2,000 & 2,550 & 1,980 & 1,632 & 2,550 \\
\hline New York & 2,592 & 2,000 & 4,000 & 2,463 & 1,900 & 4,000 \\
\hline Others & 2,272 & 2,000 & 2,808 & 2,146 & 1,976 & 2,808 \\
\hline \multirow[t]{2}{*}{ Industry Wide } & 2,336 & 1,440 & 4,032 & 2,132 & 768 & 4,032 \\
\hline & \multicolumn{6}{|c|}{ Years in Business } \\
\hline Long & 2,269 & 1,960 & 4,032 & 2,161 & 1,600 & 4,032 \\
\hline Medium & 2,321 & 1,440 & 4,000 & 2,141 & 960 & 4,000 \\
\hline \multirow[t]{2}{*}{ Short } & 2,462 & 1,440 & 4,000 & 2,071 & 768 & 2,600 \\
\hline & \multicolumn{6}{|c|}{ Production Size } \\
\hline Small & 2,123 & 1,440 & 3,016 & 1,976 & 768 & 3,016 \\
\hline Medium & 2,156 & 1,920 & 3,250 & 2,032 & 1,600 & 2,340 \\
\hline Large & 2,824 & 2,000 & 4,032 & 2,437 & 1,800 & 4,032 \\
\hline
\end{tabular}

\section{(3) Changes in Production}

An examination of hardwood lumber production volume by mill size can help visualize the impacts of the economic downturn on mills production. The average weekly production for the sawmills large to small was; 489,700 (BF), 110,974 (BF) 19,041(BF) respectively in 2008(Table 2.4). However, the production changed to 349,120 (BF) for large sawmills, 87,511 (BF) for medium sized mills and 12,263 (BF) for small sawmills in 2010. The results showed that the largest change in lumber production occurred in large sawmills (29\%) compared to small sawmills $(22 \%)$. 
The average weekly lumber production among the surveyed sawmills was 196,792 (BF) in 2008. In 2010, the weekly lumber production ranged from 700 to 600,000 (BF) with an average of 145,610 (BF), decreasing by 26 percent compared to 2008 (Table 2.4). The changes in weekly lumber production among sawmills of different production levels were statistically significant $(p=0.0248)$.

Table 2.4.- Weekly Production changes of sawmills before and after downturn.

\begin{tabular}{lcccccc}
\hline \multicolumn{5}{c}{ Weekly Production (BF) } \\
\hline & Mean & Min & Max & Mean & Min & Max \\
\hline West Virginia & 277,273 & 4,000 & $1,500,000$ & 150,667 & 3,000 & 500,000 \\
Pennsylvania & 110,906 & 800 & 465,500 & 96,353 & 700 & 465,500 \\
Ohio & 134,611 & 15,000 & 600,000 & 114,982 & 10,000 & 500,000 \\
New York & 254,640 & 53,200 & 375,000 & 229,142 & 50,000 & 400,000 \\
Others & 333,186 & 75,000 & $1,200,000$ & 234,043 & 45,000 & 600,000 \\
Industry Wide & 196,792 & 800 & $1,500,000$ & 145,610 & 700 & 600,000 \\
& & \multicolumn{7}{c}{ State } \\
Long & 143,212 & 25,000 & 350,000 & 117,324 & 25,000 & 350,000 \\
Medium & 261,358 & 800 & $1,500,000$ & 181,454 & 800 & 600,000 \\
Short & 128,983 & 3,000 & 400,000 & 103,716 & 700 & 300,000 \\
& & \multicolumn{7}{c}{ Size } & & \\
Small & 19,041 & 700 & 80,000 & 12,263 & 800 & 36,000 \\
Medium & 110,974 & 53,200 & 250,000 & 87,511 & 40,000 & 199,500 \\
Large & 489700 & 240,000 & $1,500,000$ & 349120 & 225,000 & 600,000 \\
\hline
\end{tabular}

From the GLM model results, it was found that interaction between states and production level $(\mathrm{F}=3.8 ; \mathrm{df}=5,24 ; p=0.0112)$ and interaction between business years and production level $(\mathrm{F}=3.79 ; \mathrm{df}=4,24 ; p=0.0159)$ had statistically significant effects on the changes in weekly lumber production. 
The surveyed sawmills in West Virginia produced an average of 150,667 (BF) of lumber per week in 2010, a 46 percent decrease presented compared to 2008 (277,273 (BF) per week). The maximum decrease in production was 1 million board feet (MMBF). The average decrease in production for sawmills in PA was $14,553(\mathrm{BF})$ with a maximum of $67,000(\mathrm{BF})$ per week. It was noted that one sawmill in PA that was not impacted by the economic downturn had a slight increase in production of 3,990 (BF). A significant change was detected in production for sawmills in PA $(p=0.0081)$. The average decrease in weekly lumber production for Ohio sawmills was 19,628 (BF) with a range from 0 to 100,000 (BF). Similarly, sawmills in New York also experienced a decrease in weekly lumber production with an average reduction of $25,498(\mathrm{BF})$ ranging from $6,650(\mathrm{BF})$ to $200,000(\mathrm{BF})$ decrease in 2010. It was also noted that two sawmills in New York increased their production slightly (6,650 and 4,580 (BF) per week). The results indicated that almost all the responding sawmills experienced less lumber production due to the economic downturn and low demand for wood products. There was no significant difference among states.

The changes in weekly lumber production by years in business were analyzed. The average weekly lumber production among sawmills with longer years in business reduced by 18.08 percent since the economic downturn. This number changed to 31 percent and 20 percent for sawmills with medium and short years in business, respectively. The results indicated that weekly lumber production reduced the most for the sawmills with medium and short years in business.

The average weekly lumber production reduced by 36 percent for sawmills of low production level, while this number changed 21 percent in medium production level sawmills. For sawmills with a high production level, the average weekly lumber production reduced by 29 
percent. According to the results there was a significant decrease in lumber production in small sawmills.

\subsubsection{Wood residue production}

Information on residue production on chips and sawdust in Appalachian sawmills was collected for 2010. Average residue production in the responding sawmills was 139 tons per week for chips and 81 tons per week for sawdust. The chips and sawdust production in hardwood sawmills was also analyzed based on different business years, production level, and states

(Figure. 2.1).

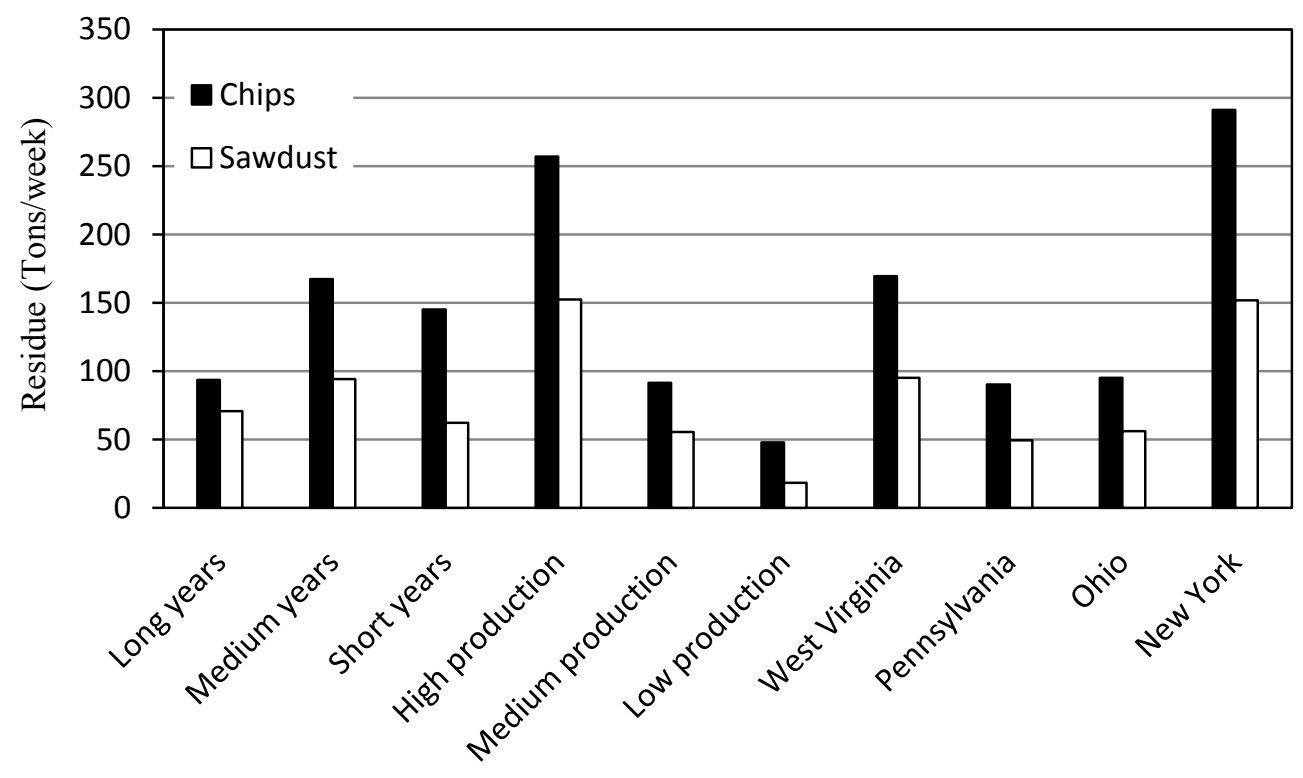

Figure 2.1.- Residue production by business years, production level and state.

The results indicated that more wood residue was produced by sawmills with medium years in business compared to long and short years in business. The average chips and sawdust production was 257 and 152 tons per week, respectively, in high production level sawmills, 
while the numbers changed to 91 and 55 tons per week in medium production level sawmills, and 48 and 18 tons per week, respectively, in low production level sawmills. The results indicated that logically more residue was produced in sawmills with a high production level. The results indicated that the most chips and sawdust were produced in West Virginia and New York, while the least amount of chips and sawdust were produced in Pennsylvania and Ohio.

Effective handling and utilization of wood residue can help improve the profits of hardwood sawmills. The utilization of wood residues in the Appalachian region was also surveyed. The results showed that most of the wood residue (37\%) was used for animal bedding \& litter, and then followed by boiler fuel, and pulp \& paper (Figure. 2.2).

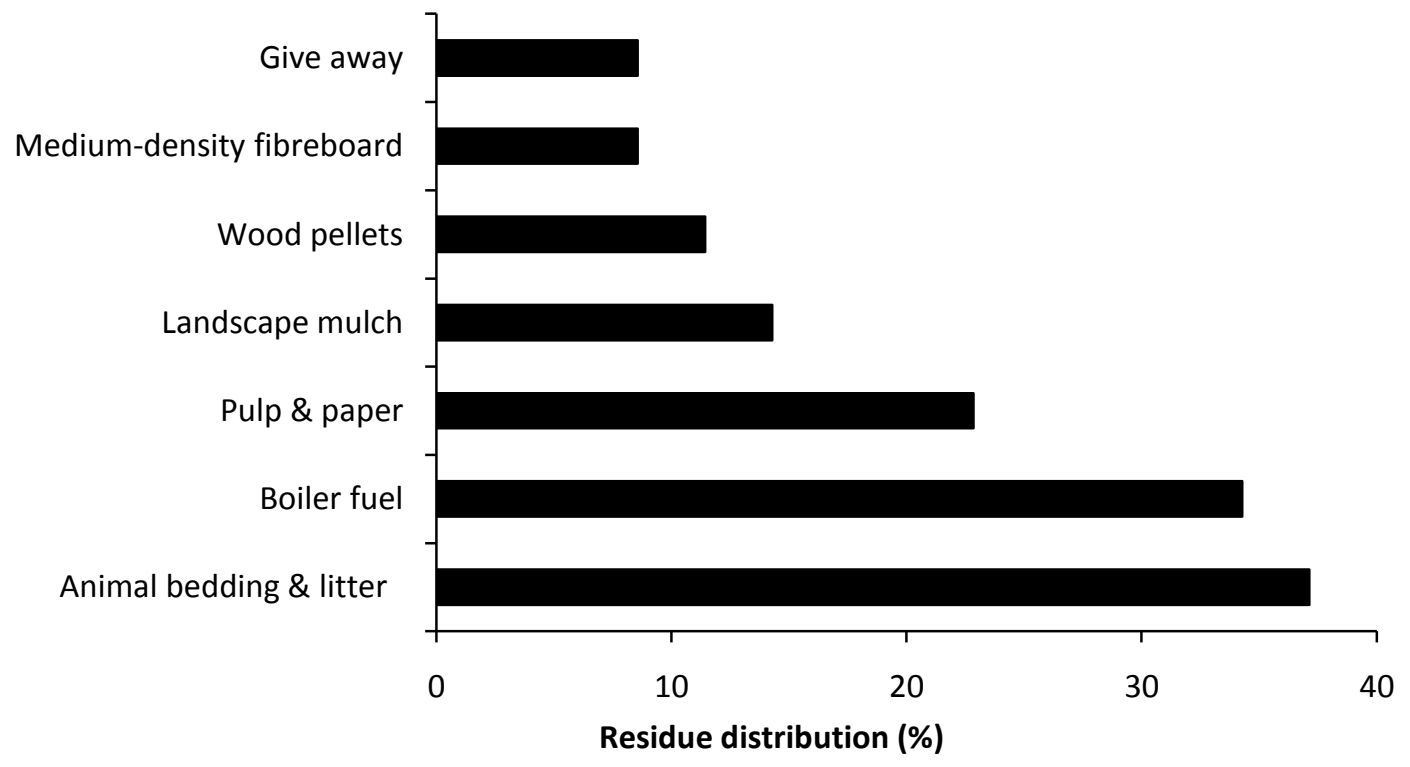

Figure 2.2.-Wood residue distribution

Other uses included landscape mulch, wood pellets, and medium-density fiber-board. Three sawmills stated that they gave away the wood residue. When further looking into these three sawmills, they were all small sawmills that didn't produce enough residue to warrant selling. 
Non-response bias was assessed by comparing the responses of early and late respondents based on the method presented by Smith et al. (2004). Early respondents were those who had responded to the first survey while late respondents were those who responded in the second survey. The results indicated that there were no significant differences in non-response bias for the interested variables (such as firm size, operation years, and production levels) when using analysis of variance (ANOVA).

\subsubsection{Hardwood sawmill profile}

A majority of the responding sawmills used circle-saw headrigs (57\%) and the remaining (43\%) used bandsaw headrigs. Circular saw headrigs were more commonly used (over 60\%) in small sawmills. During 2010 average production was 196,792 (BF) which is down 26\% compared to before the economic downturn. Employees in 2010 averaged 30 down 29\% versus before the downturn. Yearly operating hours averaged 2,132 in 2010 which indicated a decrease of $9 \%$. When collecting information on production volume and number of employees, it is important to know if the responding sawmills own a single mill or multiple facilities. Most of the surveyed sawmills are small and medium size in terms of employment, which occupies 69 percent of the total. The majority of the responding hardwood sawmills in the Appalachian region are short- and medium-term operation in terms of years in business (70\%). Most responding sawmills (89\%) currently used one shift per day. It is clear that drastic changes have happened since the economic downturn in Appalachia's sawmills.

\subsubsection{Log inventory}

The surveyed mills were asked about the number of weeks of log inventory the mill held along with an explanation for the amount of inventory. The results showed that log inventory 
across the entire sawmill industry in the region averaged six weeks in 2010 . The range of log inventory was from no inventory to fifty weeks. Sixty-four percent of the respondents stated that their log inventories decreased, 28 percent of the surveyed sawmills kept the same inventory level, and the others increased log inventory. The reasons of decreasing log inventory include, but not limited to insufficient capital for purchasing, increased competition for raw material supply, higher log prices, and weather problems. The log inventory in the responding sawmills was analyzed based on different business years, production level, and states (Figure. 2.3).

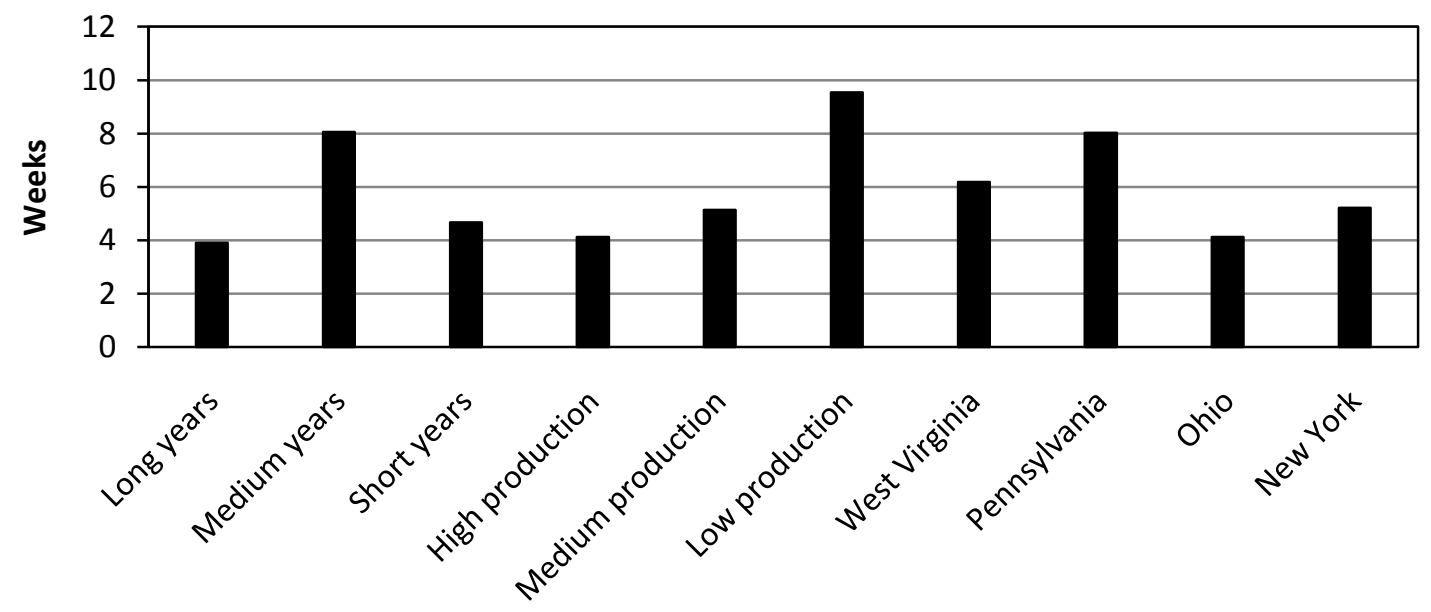

Figure 2.3.-Log inventory in sawmills for different business years, production level, and states.

It was found that sawmills with medium years in business had more log inventory compared to sawmills with long or short years in business. Sawmills with low production level kept more log inventory, which was almost two times longer than those with medium and high production levels. This could be attributed to larger mills utilizing lean manufacturing principles such as just in time inventory. Thirty-three percent of large sawmills reported utilizing lean manufacturing principles. This represented the highest percentage of mills utilizing lean 
principles out of production categories. Pennsylvania and West Virginia sawmills showed longer log inventory, compared to those in Ohio and New York.

The survey also asked whether they have problems in finding/purchasing logs or raw materials during the economic downturn. Approximately 60 percent of the respondents answered "Yes" to this question. The major reasons included: not enough loggers, profit margin decrease, competition, raw material price increase and insufficient raw material supply.

\subsubsection{Breakeven Summary}

Many sawmills have been struggling to make profits since the economic downturn that started in 2008. A great number of sawmills that are still in operation were finding it difficult to break-even while operating in this challenging economic time. The survey asked the question, "How long would you be willing to break even or lose money before shutting your company down (months)?" The average time was 18 months and 13 months, respectively. While, answers ranged from no time to sixty months. 
The breakeven operation time in months among the responding sawmills was analyzed based on different business years, production level, and states (Figure. 2.4).

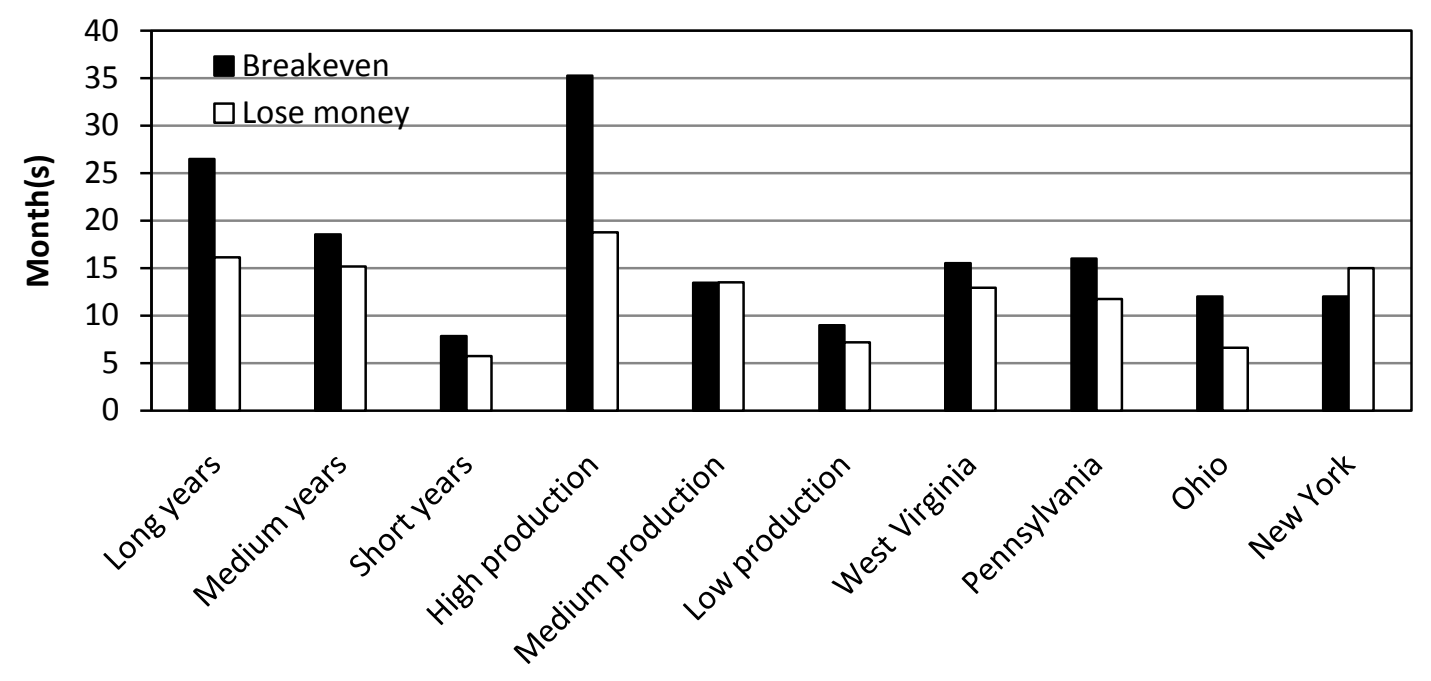

Figure2. 4.-Break even and lose money by business years, production level and state.

Sawmills that had been in business a long time allowed more time for the breakeven time compared to sawmills with medium or short business years. Sawmills that have been in business a long time seem to be more optimistic about things turning around. Large sawmills can deal easier with periods of breakeven or lose money. This is because high production mills can easily go from working two shifts to one thus reducing their output by about half. Sawmills with high production were willing to operate almost four times longer in breakeven and twice as long when losing money compared to low production sawmills. Typically a large amount of capital is invested into large facilities. If the owners are making payments it is better for the mill to be running and losing some money rather than the mill being closed and making no money. There was no distinct difference in the breakeven operation time among states. However, it was noted 
that sawmills from Ohio were reluctant to keep operating when the sawmills were losing money, compared to the other states.

\subsubsection{Market distribution and strategies}

Construction industry (furniture, flooring, cabinets and millwork), industrial commerce (pallets and railroad ties) and exports are general end markets for the hardwood industry (Manchester et al. 2009). These industries had experienced great difficulty during the economic downtown, which significantly impacted the hardwood market. The traditional markets for hardwood lumber, such as furniture and cabinetry have declined sharply. Mill owners have been forced to find new markets such as railroad ties to pick up the slack (Buehlmann et al. 2010). Typical secondary markets such as pallet stock, railroad ties, and mine timbers became a larger percentage of hardwood end use, especial for pallet manufacture (Manchester et al. 2009).

In the survey, the types of wood products produced in Appalachian sawmills during 2010 were evaluated (Figure. 2.5).

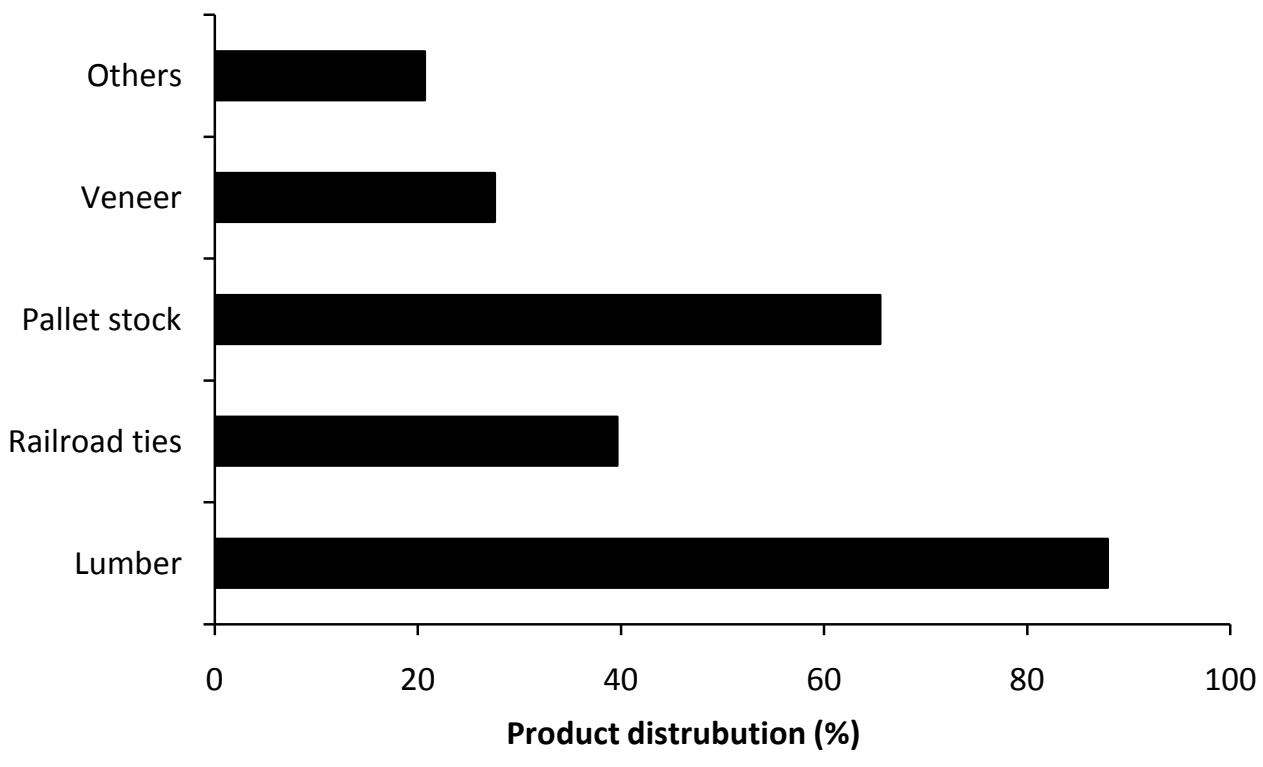

Figure 2. 5.-Wood products distribution by product type. 
The results showed that $88,40,66$, and 28 percent of the respondents produced lumber, railroad ties, pallet stock, and veneer, respectively. About 21 percent of respondents also produced other products such as rail fence, post, and mine cribbing. The results showed that sawmills usually diversified their wood product types in order to meet the market demand, and more than half of the respondents produced pallet lumber. The top three wood products produced by the surveyed sawmills were lumber, pallet, and railroad ties, which accounted for 36,30 , and 18 percent of the total. In addition, 65 percent of the respondents stated that producing lumber achieves the greatest profit margin. Although it is important to note that many sawmills are making good profit from the secondary products such as pallets since the lumber price has decreased sharply.

It was noted that the current economic downturn had dramatically decreased the profit margins for some previous high-profit lumber. For example, the prices of yellow-poplar Firsts and Seconds (FAS) boards dropped by 25 percent from January 2007 to August 2010 (Hardwood Market Report 2007, 2010). The hardest hit species was black cherry, whose market prices fell almost 54 percent (FAS board) from January 2007 to August 2010. During the same time frame, the price of No.1 common (1c) black cherry boards decreased by 55 percent. The lumber price drop coupled with high fuel surcharges of 2008 combined to spell disaster for many sawmill owners in the Appalachian as well as the other regions in the US (Hardwood Market Report 2007, 2010). The lumber species that generated the greatest profit margins among the Appalachian sawmills were analyzed based on the survey responses (Figure 2.6). Oak was the highest profit species, which accounted for 38 percent of the surveyed, sawmills, followed by hard maple (19\%), ash (17\%), and walnut (14\%). The lumber species that had the lowest profit 
margin are shown in Figure 6b. Yellow-poplar was the lowest profit species (36\%), followed by cherry (26\%) and soft maple (17\%).

(a)

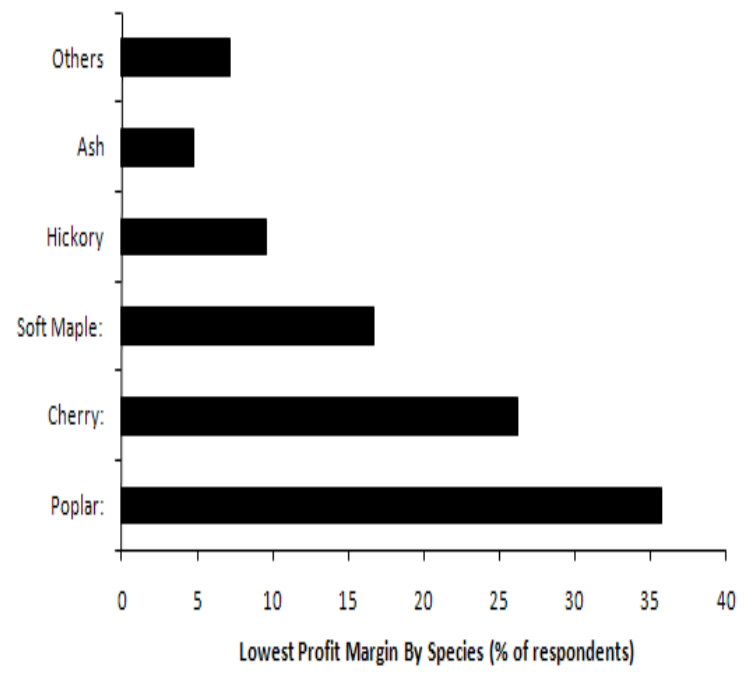

(b)

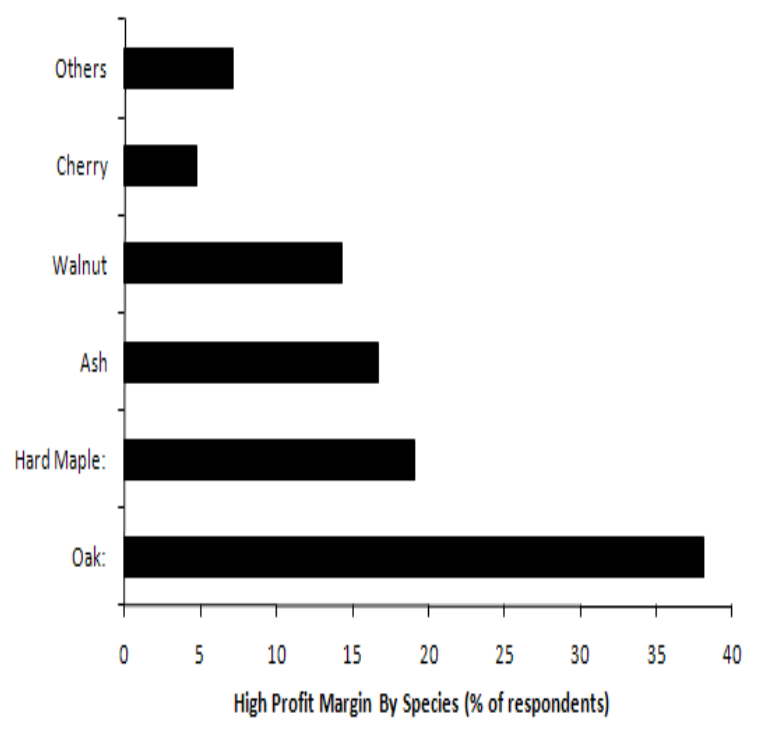

Figure 6.-(a) lowest profit margin species, (b) Highest profit margin species.

Efficient marketing is very important in maintaining profitable sawmills in the ever changing economy. Current economic conditions are challenging the commonly used marketing strategies by many hardwoods sawmills because they are insufficient in the current economy. Survey respondents were asked to list the marketing strategies currently used. The results showed that export (46\%) and advertising (38\%) were the major strategies, followed by contacting customers and finding a new market. Additional revenue can be realized by improving export strategies. In order to overcome the economic downturn in the domestic housing and furniture markets, many hardwoods sawmills have begun exploring international markets which have great demand for hardwood products. The respondents were also asked, "Have your company's marketing strategies changed because of the tough economic times?" More than half of the responding sawmills (67\%) stated that they have changed their marketing 
strategies. In order to adequately meet the needs of changing market conditions, mill managers must become more market oriented. To become more market oriented managers should contact customers to make sure their product meets the needs of the customer adequately. Sawmills need to produce products that the market demands rather than hoping someone will buy the product that is produced.

Among the exporting sawmills, more than half (55\%) of them exported both logs and lumber, 9 and 36 percent of them exported only logs or lumber, respectively. Results of the survey showed that the most frequent export destinations of the Appalachian hardwood products were China, Europe, and Canada (Figure 2.7), which were consistent with the findings of a previous survey conducted in 2008 by Wang et al. (2010). When asked how they export their hardwood products, most of the surveyed sawmills sold the products to a middleman in the U.S., then exported.

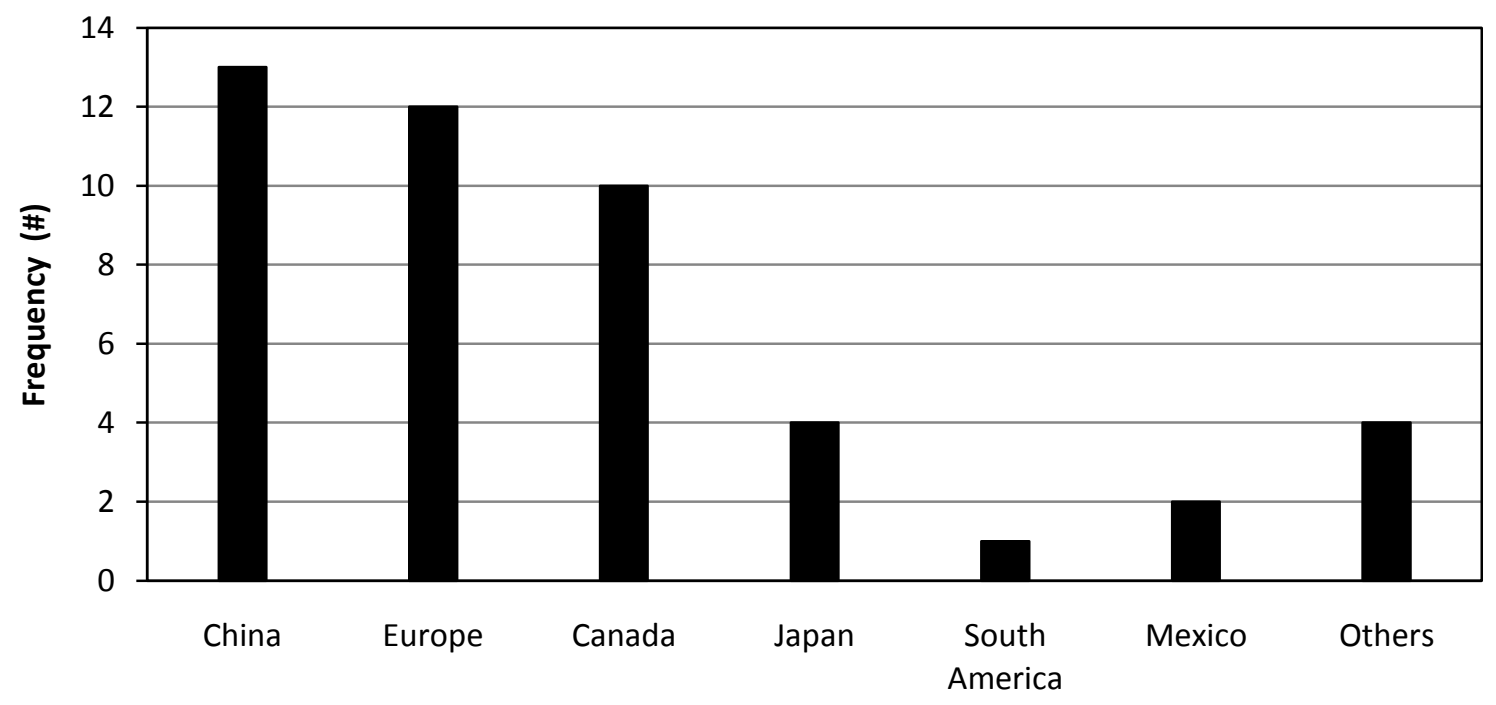

Country

Figure 2.7.-Wood products exporting countries distribution. 
To get familiar with the most current national and international markets, law and, restriction information and promote the product sale, many sawmills chose to join trade associations. Most of the respondents in the survey were members of the National Hardwood Lumber Association (NHLA) (78\%), Hardwood Manufacture's Association (HMA) (50\%), and American Hardwood Export Council (AHEC) (39\%). Transportation and payment method are still the major concerns with conducting business overseas, which is consistent with the survey by Wang et al. (2010).

Hardwood market prices have increased slightly in 2011 according to the Hardwood Market Report. However, it is still difficult for sawmills due to the low lumber demand and lower housing starts. Respondents were also asked, "When do you believe the forest products market will improve?" These answers tend to be more diverse. Most of the respondents (46\%) chose one to two years, followed by two to five years(28\%), less than 6 months $(13 \%)$, and never $(13 \%)$. The results indicated that there are still a large percentage of sawmills who are confident in the hardwood market. This also explains why those sawmills kept running even when the risk of losing money was great during the economic downturn.

\subsection{Conclusions}

This study profiled the Appalachian hardwood sawmills in 2008 and 2010 in terms of employment, operating hours, production volume, wood residue production, log inventory, breakeven or money-losing production, and marketing and exporting strategies. The survey results showed that the hardwood sawmills in Appalachia have experienced significant changes since the economic downturn of 2008. The average numbers of employees have decreased by 29 percent, and the average yearly operating hours have decreased by 9 percent, and the average weekly lumber production has decreased by 26 percent in the region. 
The changes also varied among states, business years, and production levels. West Virginia was the hardest hit by the economic downturn as apparent from the survey data. For example, the hardwood sawmills experienced a sharp drop in the number of employees and operating hours post economic downturn in West Virginia. More employees, operating hours, and weekly lumber production changes occurred in sawmills with shorter years in business. More operating hours were reduced in sawmills with a high production level, and more weekly lumber production was reduced in sawmills with low production level.

Log inventory across the industry averaged six weeks in 2010. Log inventories can have a great impact on the health of the wood industry. A fine balance exists between too much log inventory and too little inventory. Excess inventory can needlessly waste mill capital and create gaps in stumpage price verses lumber prices while too little inventory can make the mill idle. Due to the economic uncertainty of log prices managers like to keep inventory at a minimum level to reduce the risk of losing money when market prices change. To meet customers' orders, a mill manager has to select what logs to process, decide on the sawing procedures and schedule production to meet the demand on time and at a minimum cost (Mendoza and Meimban 1991). Since management of log inventory is important and difficult, using computer control software system or operation research methods to manage log inventory is necessary for hardwood sawmills to improve their profit.

Average residue production in responding sawmills per week in tons was 139 for chips and 81 for sawdust in 2010. In the last few years, the housing slump and the global economic downturn have seriously affected lumber industry. This resulted in reduced availability of wood residues. Although wood residues are being utilized for pulp chips, composite production, and fuel for dry kilns, a significant amount of wood residue enters the waste stream, thus rendering 
these underutilized renewable natural resources seems necessary (Wang 2006). Sawmills need to start realizing value-added products can also be obtained from residue instead of selling it for pennies on the dollar. Managers should actively seek new markets for products currently viewed as wastes.

The traditional commodity marketing strategy used by many hardwoods sawmills needs to change to weather the current economic downturn and housing marketing conditions. More than half of the responding sawmills (67\%) stated that they have changed their marketing strategies. The traditional markets for hardwood lumber have changed in past few years; pallets became a larger percentage of hardwood end use. Hardwood sawmills should develop relationships with their customers and search for new markets to make their wood products welcome and demanded, especially in these turbulent times.

Exporting can offer several advantages for hardwood sawmills. These advantages include the potential for increased profit, market expansion, disposing of excess products, and economic stability resulting from diversification (Naka et al. 2009). Many Appalachian sawmills are unsure of exporting products for fear of the transportation and payment method. The results found that almost half of the respondents ( $46 \%)$ stated they exported their wood products. Under the demand for hardwood lumber by foreign countries and globalization of the wood products market, hardwood sawmills should increase their wood products export to get through the current tough economic times. 


\section{References}

Buehlmann, U., O. Espinoza, M. Bumgardner, and B. Smith. 2010. Trends in the US hardwood lumber distribution: changing products, customers, and services. Forest Prod. J. 60(6):547553.

Dillman, D.A. 2000. Mail and Internet Surveys: The Tailored Design Method. Second Edition. John Wiley and Sons, Inc. New York, NY. 464pp.

Hardwood Market Report. Hardwood Market Report, 2007. Lumber News Letter, vol. LXXXV. Hardwood Market Report, Memphis, TN.

Hardwood Market Report. Hardwood Market Report, 2010. Lumber News Letter, vol. LXXXVIII. Hardwood Market Report, Memphis, TN.

Holmes, T., Golas, C., Gould, D., Martino, T., \& Cesa, E. 2010. Value added wood products marketing guide. Newtown Square, pa: Northeastern Area State and Private Forestry Forest Service, U.S. Department of Agriculture.

Hedlund, A. 2011. Economic forecast: Recovery with bright spots, turmoil. Tribune 16 June 2011, Print.

Luppold, W.G. 1995. Effect of the hardwood resource on the sawmill industry in the central and Appalachian regions. In: Gottschalk, Kurt W.; Fosbroke, Sandra L. C., ed. Proceedings, 10th Central Hardwood Forest Conference, Morgantown, WV. Gen. Tech. Rep: 481-487.

Luppold, W. G., J. Baumgras, and G. Barrett. 2000. Characteristics of the eastern "grade" hardwood sawmilling industry. Forest Prod. J. 50(9): 23-27. 
Luppold, W. G. 2009. The North American Hardwood Market: Past, Present, and Future. http://www.fcba.fr/ischp/ischp.ca/FR/pdf/1_comsession1/Luppold_northamerican.pdf. Accessed May 1, 2011.

Manchester B., W. Adrian, M. Jason, and T. James. 2009. The hardwood sawmill market. http://www.mcgladreycm.com/Portals/0/InTheNews_PDF/MCMHardwoodsReport.pdf. Accessed May 1, 2011.

Mendoza, G. and M. Roger. 1991. Combined Log Inventory and Process Simulation Models for the Planning and Control of Sawmill Operations. Proceedings, 23rd CIRP International Seminar on Manufacturing Systems. 8pp.

Naka, K., B. A. Parsons, and A. L. Hammett. 2009. Hardwood lumber industry in the Appalachian region: focus on exports. Forestry Chron. 85(1):75-81.

Smith, R., P. Wibke, P. Araman, and D. Cumbo. 2004. Characterizing the adoption of low-grade hardwood lumber by the secondary wood processing industry. Forest Prod. J. 54(12), 15-24.

UNECE. 2009. Forest Products Annual Market Review 2008-2009.

http://timber.unece.org/fileadmin/DAM/publications/ExecutiveSummary2009FPAMR.pdf. Accessed May 1, 2011.

Wang, J., J. Wu, D. DeVallance, and J. Armstrong. 2010. Appalachian hardwood product exports - An analysis of the current Chinese market. Forest Prod. J. 60(1): 94-99.

Wang, J., J. Wu, and J. Armstrong. 2010. An analysis of Appalachian hardwood products in the Chinese market. Wood Fiber Sci. 42(1): 71-80. 
Wang, J., S. Grushecky, and J. McNeel. 2006. Biomass resources, uses, and opportunities in West Virginia. Biomaterials Center, Division of Forestry and Natural Resources, West Virginia University, Morgantown, WV. 116 pp. 
CHAPTER 3: ENERGY CONSUMPTION AND EFFICIENCY OF HARDWOOD SAWMILLS IN THE APPALACHIAN REGION ${ }^{2}$

\footnotetext{
${ }^{2}$ To be submitted to Forest Products Journal
} 


\begin{abstract}
A study of energy consumption and efficiency for hardwood sawmills was conducted in the Appalachian region. Primary data were collected through a mail survey on sawmills in the Appalachian region, while secondary data were collected from site audits at 17 sawmills in West Virginia. The mail survey results showed that the average electricity consumed per month was $356 \mathrm{MMBtu}$ or $107,007 \mathrm{kWh}$ with an average electric bill of $\$ 9278$ per month. Based on the respondents who used natural gas, its consumption averaged 1,125 thousand of cubic feet (MCF) per month with an average gas bill of $\$ 5,703$. The energy audit results indicated that the average energy conserved per mill was 916 MMBtu or 275,110 kWh. The carbon dioxide emission conserved was 587,045 lbs per month per mill. The average marginal cost was $\$ 17.87 / \mathrm{MMBtu}$ ( $\notin 6.10 / \mathrm{kWh}$ ), while the energy use per MBF of lumber production averaged $160.89 \mathrm{kWh} / \mathrm{MBF}$. The average processing cost was $\$ 10.04 / \mathrm{MBF}$ ranging from $\$ 0.81 / \mathrm{MBF}$ to $\$ 22.01 / \mathrm{MBF}$. The average potential energy savings was 15 percent of the annual energy used. The potential savings ranged from $9 \%$ to $25 \%$.
\end{abstract}

Keywords: energy audit, energy usage, lumber processing, primary processing, sawmilling, Appalachian hardwood. 


\subsection{Introduction}

The efficiency of lumber production and energy consumption has been a major concern to hardwood sawmills operators. Currently, hardwood sawmills are experiencing low demand and falling profits since the recent economic downturn. The production of hardwood lumber in the US has fallen 25 percent since 2000 (Parhizkar et al. 2009). The eastern hardwood lumber production declined by 23 percent between 1997 and 2008, and the hardwood production in the Appalachian region has declined by more than 40 percent (Luppold 2009, Wang et al. 2010). Especially during 2008-2009, the US financial and economic crisis escalated and spread globally, causing devastating effects on the hardwood products industry in the region.

One of the ways for cost-saving consideration is through energy conservation. Energy costs in a typical sawmill facility can range between 1 and 10 percent of the total operating costs (Mardikar 2007). In the past, energy cost was typically overlooked because it was a relatively cheap input compared to other inputs in sawmills. However, recently more attention is being given to energy consumption with today's spiraling energy prices (Mate 2002). The rising cost for energy (e.g. natural gas, electricity, and fuels) has a significant impact on the profit margin of lumber manufacturers, which is typically about 3-4 percent (Bond 2008). The price of natural gas for industrial use has more than doubled from 1997 to 2007, and electric energy prices have increased 40 percent during the same period (US Department of Energy 2008). Both energy sources accounted for about 25 percent of total energy consumption by the sawmill industry (Bond 2008). Inefficient energy use in sawmills is becoming more and more expensive, which is increasing operating costs. Therefore, it is necessary to examine the energy consumption and efficiency for hardwood 
sawmills in the Appalachian region. To find ways to improve the long term profitability of the regions sawmills.

Wood processing industries consume a large amount of energy in the forms of electricity and heat. The forest products sector uses $12 \%$ of the total energy input for the U.S. manufacturing industry, which includes $5 \%$ that is consumed by the lumber manufacturing industry (hardwood and softwood sawmills) (Bond 2008). In 2001, the lumber manufacturing industry spent $\$ 368$ million for electricity and $\$ 128$ million for fuels (Bond 2008). A typical hardwood sawmill usually five main operations including log debarking, log sawing, flitch edging and trimming, side-cuts chipping, and lumber drying. If a sawmill only produces rough green lumber and has no kiln-drying facility, electricity will be the primary energy consumption, otherwise heat will be the most important component of their energy usage. Kiln drying is the most energy intensive process in the production of surfaced dry lumber, which uses 6 to 9 times more energy than the sawmilling operation itself (Wengert and Meyer1992).

It is very important for sawmill operators to understand the significance and opportunities of energy consumption and efficiency. Increased energy efficiency means reducing energy consumptions and costs (Bond 2008). Several related studies have been conducted on energy efficiency of sawmilling practices (Armstrong and Brock 1989, Wengert and Meyer 1992, Hutchinson et al. 1998, Poole and Pinheiro 2003, Gopalakrishnan et al. 2005, Li et al. 2006, Mardikar 2007). Armstrong and Brock (1989) investigated 129 mills in the central Appalachian region to analyze fuel consumption for drying lumber. They found that wood residues were used as either the principal or secondary fuel stock by 64 percent of respondents. Wengert and Meyer (1992) reported the importance of understanding electric bills and its components to help reduce energy consumption. Hutchinson et al. (1998) addressed the 
terminology used by electricity utilities, how electricity was billed, and how to reduce the amount paid for electricity by controlling its use. Poole and Pinheiro (2003) developed energy-load profiles for sawmills in the Amazon region. They believed that developing load profiles helps to identify a baseline for energy use by sawmills. Gopalakrishnan et al. (2005) analyzed the energy utilization profile of several wood processing facilities in West Virginia. They examined the production system parameters in terms of throughput and nature of manufacturing operations in relation to the overall energy utilization, specific energy consumption, and potential for implementation of energy efficiency measures. Li et al. (2006) established an empirical model of energy demand in a sawmill based on a commercial operation. Mardikar (2007) developed a user-friendly and interactive Baseline Electrical Energy Consumption in Wood Processing Sawmills (BEECWPS) to assist users develop an energy profile based on the sawmill process dynamics and to provide real-time information about the process and production details.

To survive under the current difficult economic and market conditions, it is necessary to improve the sawmilling efficiency, search for new markets, and reduce operation costs. The objective of the paper is to examine the energy consumption and efficiency in hardwood sawmills in the Appalachian region, particularly in the state of West Virginia. Specifically, were to: (1) assess the energy consumption of hardwood sawmills in the Appalachian region, (2) provide recommendations to sawmills regarding effective ways of reducing both energy consumption and costs, and (3) determine energy conservation opportunities by conducting energy assessments. 


\subsection{Materials and Methods}

A formal mail survey of the Appalachian hardwood sawmills was conducted to gather general energy consumption and efficiency information. The survey was designed using the Dillman's tailored design method (Dillman 2000). The mailing list of Appalachian hardwood sawmills was obtained from NHLA (National Hardwood Lumber Association) (NHLA 2008), the Appalachian Regional Commission (ARC), and related state agencies. Approximately 776 firms were identified as hardwood sawmills in the Appalachian region and were selected as the sample population. The survey was conducted in the summer of 2010 .

A total of 238 responses were received, of which 58 surveys were usable. They included 21 from Pennsylvania, 16 from West Virginia, 8 from Ohio, 6 from New York, and 7 from other states including Connecticut, Maryland, Missouri, and South Carolina. One hundred and twenty three surveys were returned due to undeliverable or address change and other 57 returned replies either returned the blank forms, or provided insufficient information, or those firms were no longer in the hardwood sawmill business. Thus, the adjusted response rate of this survey was 9.9 percent. The questions were designed in relation to concerns about monthly the cost of electric and gas bills, the efficiency of electric motors utilized along with the percentage of total motors being highly efficient, number and type of air compressors, number of dry kilns, kiln capacity, type of fuel used, and electricity and natural gas used monthly. The survey also asked if any energy efficient upgrades were going to be made in 2010. Returned surveys were examined for completeness and usability, and were then entered into Excel spreadsheets and analyzed using the Statistical Analysis System (SAS).

In addition, energy audits were conducted at 17 hardwoods sawmills in West Virginia by the Industrial Assessment Center (IAC) at West Virginia University. These assessments were 
conducted over 10 years, from November 2001 to November 2010, and concentrated on energy conservation. Based on the collected historic data, energy conservation opportunities and recommendations were determined to help sawmills conserve energy and reduce carbon dioxide emissions. After identifying potential opportunities in energy conservation and energy management, the information such as electrical consumption, hours of operation, and load factor were measured on major energy consumption equipment. The recording devices such as electrical power analyzers, digital stroboscopes, and temperature guns were used in the data collection process. Motor Master Software was used to analyze the collected data, especially for electrical motors (Mate 2002).

\subsection{Results and Discussion}

\subsubsection{Profile of surveyed sawmills}

A majority of the respondents used circle-saw headrigs (57\%) and the remaining (43\%) used bandsaw headrigs. Among the respondents, 74 percent reported being a single facility while 26 percent stated being a multiple facility. When asked how many shifts per week in their operations, most of the responding sawmills (89\%) currently used one shift per week. The number of employees per mill averaged 30 with an average weekly lumber production of 145,610 (BF). In small sawmills (<40,000 (BF)) 3,749 BF/employee was produced while, medium mills (40,000-200,000 (BF)) produced 3,760 BF/employee. Large sawmills

$(>200,000(\mathrm{BF}))$ were by far the most efficient with a production of 4,498 BF/employee. This can be attributed to more automation in the mill and the use of better technology at large sawmills. Likewise, the number of employees per 100,000 BF as followed: 26, 26, and 22 for small medium and large mills respectively. The annual operating hours of the responding 
sawmills in 2010 averaged 2,132 hours. Average residue production among the respondents was

\begin{tabular}{lcccc}
\hline Variable & Mean & $\begin{array}{c}\text { Standard } \\
\text { Deviation }\end{array}$ & Min & Max \\
\hline Operating hours & 2,132 & 515 & 768 & 4,032 \\
Number of employees & 30 & 39 & 0 & 200 \\
Production (BF per week) & 145,610 & 150,489 & 700 & 600,000 \\
Log inventory (weeks) & 6 & 8 & 0 & 50 \\
Chips per week (tons) & 139 & 166 & 0.2 & 1000 \\
Sawdust per week (tons) & 81 & 101 & 0 & 500 \\
\hline
\end{tabular}

139 tons per week for chips and 81 tons per week for sawdust (Table 3.1).

Table 3.1.- Operating statistics of surveyed sawmills in 2010.

It is noted that most of the respondents used electricity as the main energy resource, very few used natural gas. The electricity consumed per month per mill averaged 107,007 kWh, and the average of electric bill was $\$ 9,278$ per month, with an average electric cost rate of $\$ 0.0867 / \mathrm{kWh}$. In the surveyed sawmills, the average total cost per MBF of production based on audit year was ranged from $\$ 4.48$ to $\$ 48.40$ with an average of $\$ 15.43$. The extreme high value of $\$ 48.40$ came from a very small sawmill with only $500 \mathrm{BF}$ of production. This value was very high because of the small amount of production while lighting costs, heating and cooling costs were similar to larger sawmills. The average industry wide was $\$ 15.43$ compared to the 
energy audit average of $\$ 9.46 / \mathrm{MBF}$ this difference can mostly be attributed electric being substantially cheaper in West Virginia. Based on the respondents who used natural gas, the average consumption of natural gas per month was 1,125 thousand of cubic feet (MCF), and the average gas bill was $\$ 5,703$ per month. So the average natural gas rate was $\$ 5.07 / \mathrm{MCF}$. The average ratio of the annual electrical energy consumption in kilowatt hours $(\mathrm{kWh})$ per year to the annual production in thousand board feet (MBF) was $220 \mathrm{kWh} / \mathrm{MBF}$. When asked whether mills have plan on making upgrades to their mill to make it more energy efficient in 2010, only about 18.8 percent of the respondents answered "Yes".

\subsubsection{Major energy systems (1) Motor systems}

Electric motors are frequently used by hardwood sawmills in the Appalachian region and are the major electricity-consuming units. The survey asked two questions about electric motors, "Does your company utilize high efficiency electric motors?" and "What efficiency are the electric motors that your mill runs?" About 54 percent of the respondents stated that they utilized high efficiency electric motors ( $94 \%$ or better). About 38,45 , and 17 percent of the respondents ran electric motors at 80-90 percent, 91-94 percent, and 95 percent or more efficiency, respectively. As evident from the survey data more attention needs to be paid to efficiency of electric motors. Several methods could be used by hardwood sawmills to reduce the cost of motor systems. The simplest way to reduce the electricity consumption of motors is to switch them off when they are idle. This can be done manually or through automatic control. Regular maintenance will ensure that motors are running at top efficiently. Proper maintenance also reduces motor breakdowns and extends the longevity of the motor. However, regular maintenance incurs expense and causes downtime. Mill 
managers should find a good balance between regular maintenance and running times. In addition, mill managers also need to examine the motor sizes utilized to make sure the motor is not oversized and needlessly wasting energy. A motor management system such as MotorMaster+ is an important tool to improve energy consumption and efficiency. Motor master helps to identify the best option regarding a decision on repairing or replacing a motor. Features of this program include; inventory management tools, maintenance log tracking, efficiency analysis, savings evaluation, energy accounting and environmental reporting.

\section{(2) Lighting systems}

The efficient use of light is essential for sawmills to reduce electric energy cost. However, lighting is often overlooked at mills. Different lighting systems have different efficiencies. For example, the efficiency of incandescent, fluorescent, mercury vapor, and sodium was 10, 20, 24, 33 percent, respectively (Wengert and Meyer 1992). In this survey, about 54 and 13 percent of the respondents used fluorescent lighting and incandescent bulbs, respectively. It was also noted that 33 percent of the respondents used both above lighting systems. Therefore, electric energy savings can be achieved in sawmills through using more energy efficient lighting systems, such as mercury vapor lamps or high-pressure sodium lamps.

One way for a mill to reduce electricity consumption is to turn off lights when they are not needed. Replacement of inefficient lights with new energy efficient lighting is highly recommended.

\section{(3) Air compressor systems}

Compressed air plays an important role in many automating processes in a typical hardwood sawmill. Wengert and Meyer (1992) pointed out that the most inefficient use of electrical energy is in compressing air at sawmills. About 40 and 50 percent of the responding 
sawmills used conventional air compressors and high efficiency screw-drive air compressors, respectively. Other 10 percent of the respondents used both types of air compressors. Screwdrive air compressors can create a much larger volume of air, with less energy, thus making them substantially more energy efficient (Elliot 2006). Newer screw-drive air compressors typically have a throttling device that controls the amount of air getting compressed at any given time compared to the amount of air needed. This feature helps increase compressor efficiency. Air leaks are a main problem for air compressors, identifying and preventing air leaks can reduce electricity consumption substantially. A considerable amount of money can be saved by simply fixing air leaks throughout the mill. Fixing air leaks is typically a simple and cost effective method to reduce energy consumption. Another problem involves over pressurizing of compressed air. The use of low pressure air is more efficient than higher pressure air (Wengert and Meyer 1992).

\section{(4) Drying kiln systems}

Rough green lumber sawn from hardwood logs is usually dried in conventional dry kilns using wood and fossil fuels as heat sources (Denig et al. 2000). Kiln drying lumber is an energy intensive process and can consume up to $60 \%$ to $70 \%$ of the total energy needed to manufacture lumber (Breiner et al. 1987, Simpson 1991). Respondents on average owned 5 dry kilns, and the average capacity of all dry kilns was 4,521 MBF per year per mill. The electricity per month per mill used for kilns was $64,125 \mathrm{kWh}$ with an average electricity bill of $\$ 5,560$. Sawmills produce a large amount of wood residues during the production of lumber. Some large mills are already burning their wood residues in boilers to produce heat for their kiln dryers. For those responding sawmills that need to dry lumber, the average total monthly residue consumption was approximately 467 tons. There are many energy saving opportunities in kiln drying. Air drying 
is a good practice to reduce heating energy before kiln drying lumber. Regular maintenance on devices such as valves and vents are necessary to prevent heat from escaping. Sawing accuracy also has an effect on the lumber drying process (Bond 2008). In addition, using efficient and suitable size boiler will increase energy savings (Wengert and Meyer 1992).

\subsubsection{Energy audit conservation opportunities}

The major wood product in the audit sawmills was lumber and the main energy use was electricity. Most sawmills operated only one shift per day. Some basic statistics of energy audits of 17 sawmills between 2001 and 2010 is presented (Table 3.2).

Table 3.2. Energy audit statistics of sawmills between 2001 and 2010.

\begin{tabular}{lcccc}
\hline Variable & Mean & $\begin{array}{c}\text { Standard } \\
\text { Deviation }\end{array}$ & Min & Max \\
\hline Operating hours & 2,951 & 1,196 & 1,728 & 5,508 \\
Number of employees & 56 & 52 & 17 & 185 \\
Production (MBF per year) & 55,444 & 129,954 & 4,250 & 400,000 \\
Audit Implementation cost $(\$)$ & 18,633 & 27,099 & 1,437 & 105,483 \\
Energy usage (kWh/yr) & $2,782,659$ & $3,633,416$ & 316,916 & $11,561,562$ \\
Energy conserved (kWh/yr) & 275,110 & 267,745 & 21,954 & $1,100,514$ \\
CO2 emission saved $(\mathrm{lbs})$ & 587,045 & 566,622 & 48,079 & $2,410,091$ \\
\hline
\end{tabular}

The average operating hours were 2,952, and average number of employees per mill was 56. The annual production of lumber averaged 55,444 (BF). Energy usage and conserved per mill averaged 2,782,659 kWh and 275,110 kWh per year, respectively. The average carbon dioxide emission conserved was 587,045 lbs. 


\subsubsection{Assessment recommendations}

Approximately 6 to 11 assessment recommendations were made for each sawmill with an average of 8 (Table 3.3). The seven most common recommendations issued to sawmills, by frequency, are illustrated in Figure 3.1. The implementation of a motor management system such as MotorMaster+ software can identify and analyze motor driven systems for various energy conservation opportunities. Changing standard V-belts with an efficiency of about $92 \%$, with energy efficient cog belts can increase the efficiency of a drive system by $2 \%$ to $8 \%$ (Oregon Department of Energy 2007).

Table 3.3.- Energy audits of sawmills between 2001 and 2010.

\begin{tabular}{|c|c|c|c|c|c|c|}
\hline $\begin{array}{l}\text { Audit } \\
\text { year }\end{array}$ & $\begin{array}{l}\text { Avg. \# of } \\
\text { employees }\end{array}$ & $\begin{array}{l}\text { Avg. total } \\
\text { operating } \\
\text { hours } \\
\text { (hrs } / \mathrm{yr})\end{array}$ & $\begin{array}{c}\text { Avg. } \\
\text { production } \\
\text { (MBF/year) }\end{array}$ & $\begin{array}{l}\text { Avg. assessment } \\
\text { recommendations }\end{array}$ & $\begin{array}{l}\text { Avg. } \\
\text { recommendations } \\
\text { implement cost } \\
\text { (\$) }\end{array}$ & $\begin{array}{c}\text { Age. } \\
\text { recom- } \\
\text { mended } \\
\text { energy } \\
\text { Savings } \\
(\$ / y r)\end{array}$ \\
\hline 2001 & 65 & 3,900 & 6,197 & 7 & 8,162 & 25,866 \\
\hline 2003 & 67 & 3,254 & 87,456 & 8 & 28,324 & 34,858 \\
\hline 2004 & 105 & 2,275 & 203,000 & 11 & 47,795 & 77,749 \\
\hline 2005 & 24 & 2,184 & 7,000 & 6 & 1,437 & 3,502 \\
\hline 2007 & 61 & 4,080 & 40,000 & 11 & 17,734 & 16,593 \\
\hline 2008 & 19 & 2,064 & 4,985 & 7 & 3,697 & 6,656 \\
\hline 2009 & 47 & 3,536 & 12,500 & 9 & 17,103 & 15,396 \\
\hline 2010 & 19 & 1,864 & 5600 & 8 & 5,698 & 4,403 \\
\hline
\end{tabular}




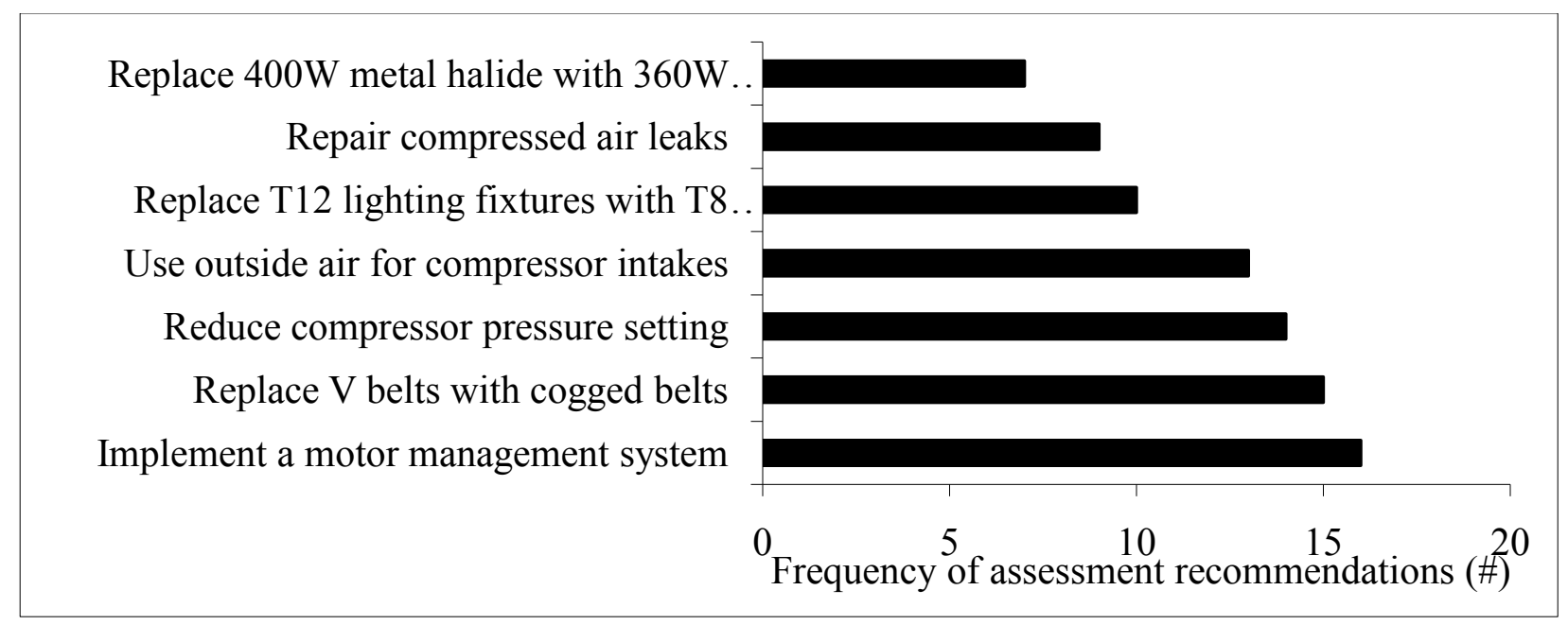

Figure 3.1.- Energy efficiency recommendations issued to sawmills.

The energy required to compress and deliver air increased by $1 \%$ for every 2 -psi increase in pressure. Thus, reducing compressor pressure settings can reduce the energy consumption of compressors. Outside air requires less energy to compress compared to indoor air (because outside air is typically cooler thus easier to compress), using the outside air should reduce the compressor energy consumption. Replacing the existing T12 lighting ballasts and bulbs with T8 bulbs with electronic ballasts and reflectors can save up to $50 \%$ energy on lighting. Repairing air leaks can increase the energy savings by reducing the amount of time the compressor has to be operated to produce the air that is lost in the leaks. Replacing 400W metal halide with 360W metal halide bulbs can also reduce the amount of energy used for lighting by about ten percent (Oregon Department of Energy 2007).

Implementation cost for assessment recommendations at sawmills ranged from $\$ 0$ to $\$ 100,000$ with an average of $\$ 18,633$. Some assessment recommendations could be easily done and the cost could be low, even with no cost under some circumstances. For example, it would be very inexpensive to turn off lights when the mill is not running, while $\$ 100,000$ was 
needed to replace the existing natural gas boiler with sawdust boiler. The mill with the natural gas boiler could switch to burning mostly wood residue which would be much cheaper. The average payback period was 8 months based on the average energy savings and implementation costs. Similarly, as the implementation cost varied for each recommendation, the payback period was also different. The payback period ranged from immediate to 2.6 years. The payback period for switching off equipment when idle was immediately, and 2.6 years was needed to install capacitor banks to reduce electrical spikes.

\subsubsection{Marginal cost and energy usage}

The marginal cost of electricity per MMBtu is calculated by dividing the total cost of electricity by the total MMBtu of electricity consumed (Mate 2002). The average marginal cost of MMBtu based on audit year was $\$ 18.36 /$ MMBtu $(\$ 6.3 / \mathrm{kWh})$ ranging from $\$ 11.25 /$ MMBtu $(\$ 3.8 / \mathrm{kWh})$ to $\$ 34.9 /$ MMBtu $(\$ 11.0 / \mathrm{kWh})$. Some of the sawmills had a large demand cost, and energy consumed per year was higher compared to other mills. Demand cost is a fluctuating fixed cost based upon the number of $\mathrm{kWh}$ of electric that is used. Upon closer observation some of the mills with high energy usage had dry kilns while one other mill manufactured wood pellets. As mentioned previously drying lumber takes six to nine times the amount of energy required to saw lumber.

Marginal cost is calculated by dividing the total annual energy consumed in $\mathrm{kWh}$ by the annual production of lumber in MBF. The energy use per MBF of production based on audit year averaged $138 \mathrm{kWh} / \mathrm{MBF}$, ranging from $58 \mathrm{kWh} / \mathrm{MBF}$ to $287.78 \mathrm{kWh} / \mathrm{MBF}$ (Figure 3.2). 


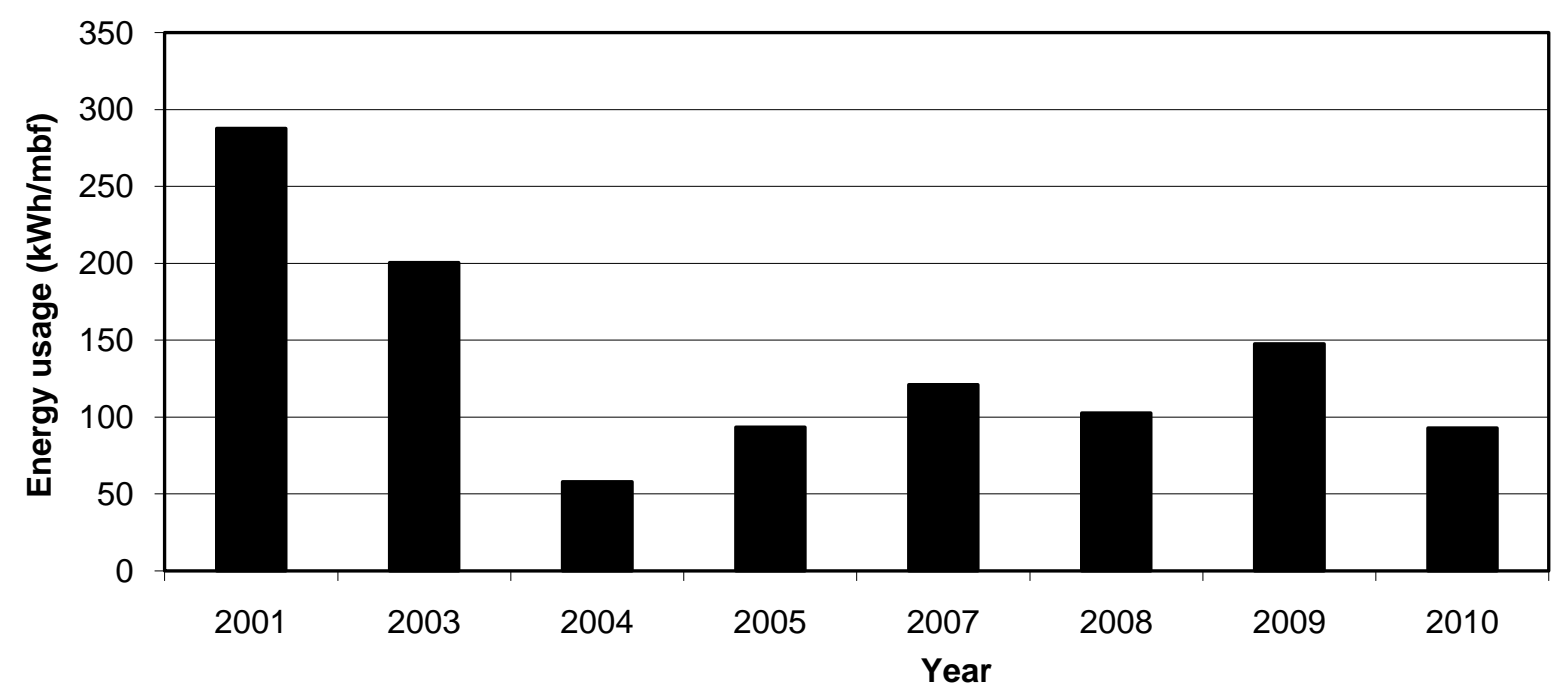

Figure 3.2.-Average energy usage per MBF of lumber production by year.

The energy usage per MBF of production was very high in 2001 because less volume of lumber was produced, while energy usage per MBF of production was low in 2004 because of the large volume of lumber produced as compared to other years. When further analyzing energy usage based on wood production in all energy audits, it was found that energy efficiency was better in large production mills as compared to small production mills (Figure 3.3). 
(a)

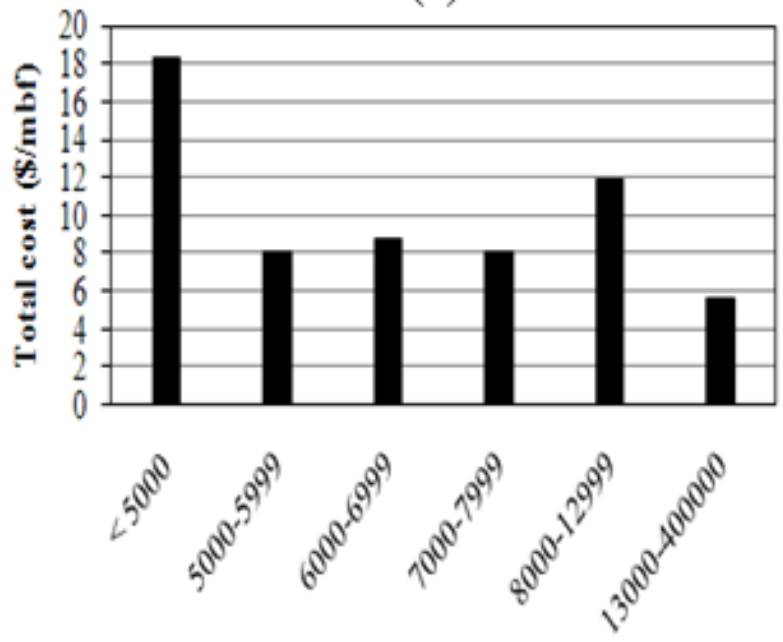

Lumber production levels (mbf)

(c)

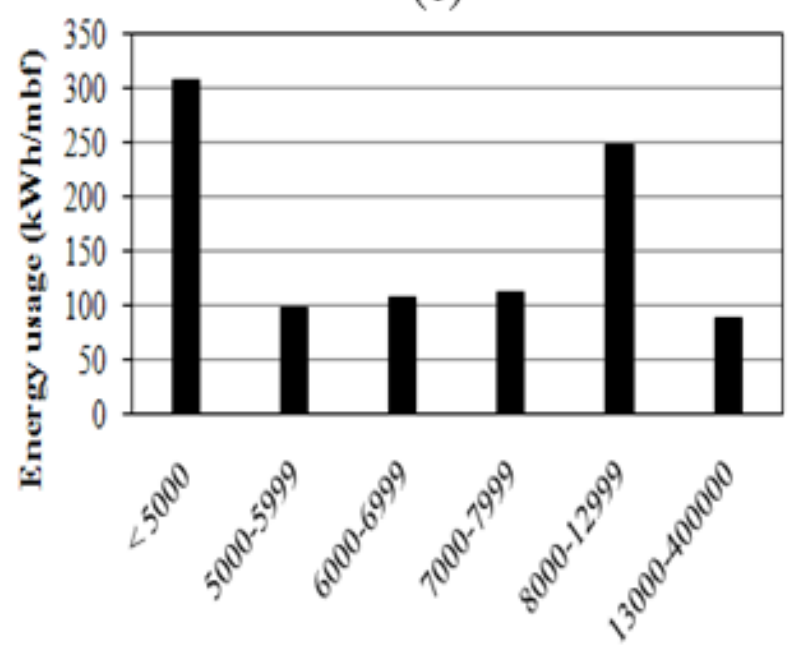

Lumber production lerels (mbf) (b)

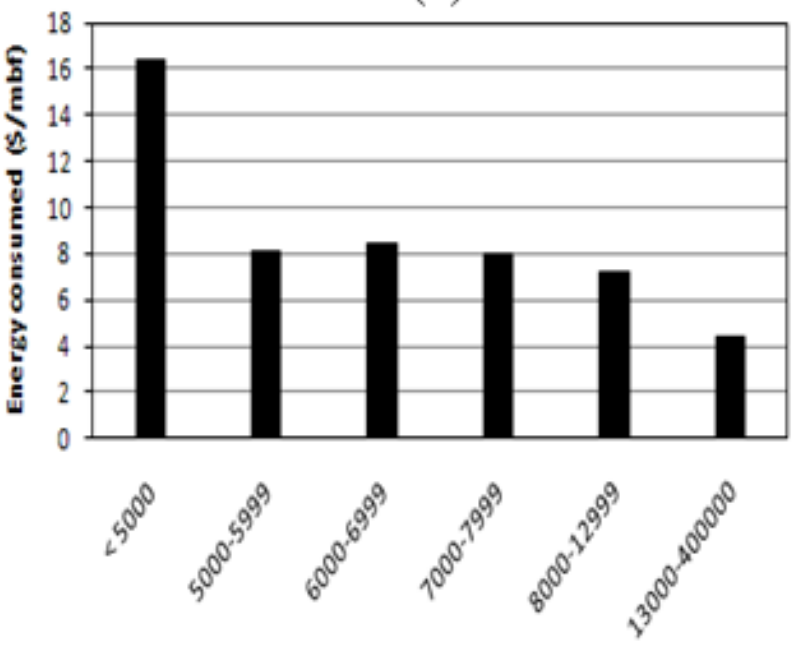

Lumber production lerels (mbf)

Figure 3.3.- Energy usage and costs by production level, (a)Total energy cost in $\$ / M B F$, (b) Energy consumed $\$ / M B F$ (excludes demand rate and taxes), (c) Energy usage ( $k W h / M B F$ ).

The correlation between production level, \$/MBF and energy usage, $\mathrm{kWh} / \mathrm{MBF}$ seems to be weaker than expected. This can be attributed to the wide variation in electricity rates industry wide and the difference in demand rate cost. 
The $(\$ / M B F)$ is obtained by dividing the total cost of the facility by the annual MBF of lumber production. It is observed that the total cost per MBF of production showed almost the same pattern as the energy usage per MBF of production for all the mills (Figure 3.4).

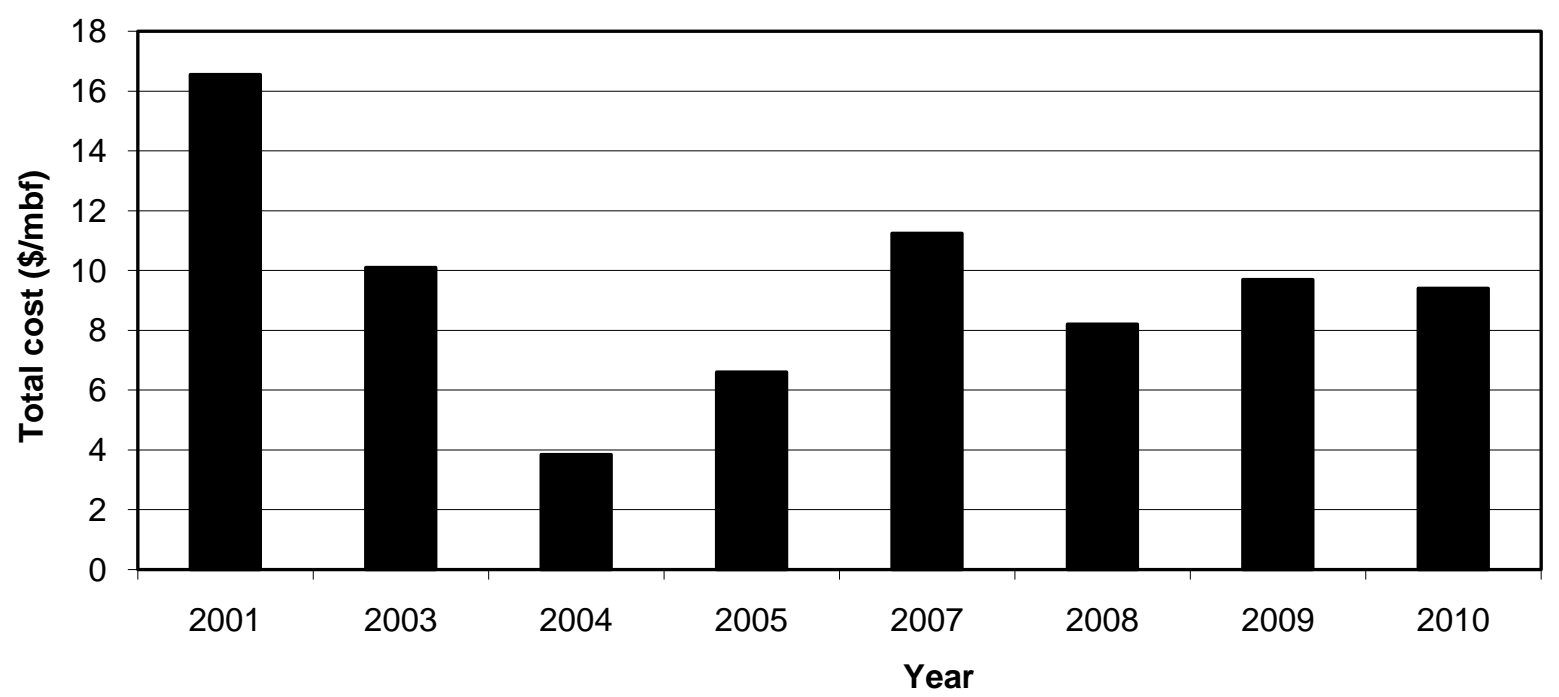

Figure 3.4.-Average total cost per MBF of lumber production based on audit year.

The total cost includes energy usage cost and energy demand cost. The demand cost can be calculated by multiplying demand rate in $\$ / \mathrm{kWh}$ by demand used in $\mathrm{kW}$ month/year. In all the audit sawmills, the average total cost per MBF of production based on audit year was $\$ 9.46 / \mathrm{MBF}$, ranging from $\$ 3.85 / \mathrm{MBF}$ to $\$ 16.56 / \mathrm{MBF}$. If no demand cost was charged by the utility company the total cost can be obtained by multiplying the energy usage values of $\mathrm{kWh}$ by the rate $\$ / \mathrm{kWh}$. Otherwise, demand cost will be added to the total cost. In some cases, demand charges can be a significant portion of the total electricity charges. In one of the audits, demand costs amounted to as much as $52 \%$ of the total electricity costs. Therefore, it is necessary to assess ways to reduce demand costs. 
Sawmills have many options to reduce demand charges, one of the ways is to downsize electric motors or get higher efficiency motors since motors are the largest consumer of electricity in the conversion from logs to lumber.

\subsubsection{Energy conservation potential}

The percent of conserved energy is calculated by dividing energy conserved in dollars by the energy used per year. The average energy savings achieved based on audit year was 13.18 percent of the annual energy used, ranging from 8.27 to 25.42 percent (Figure 3.5).

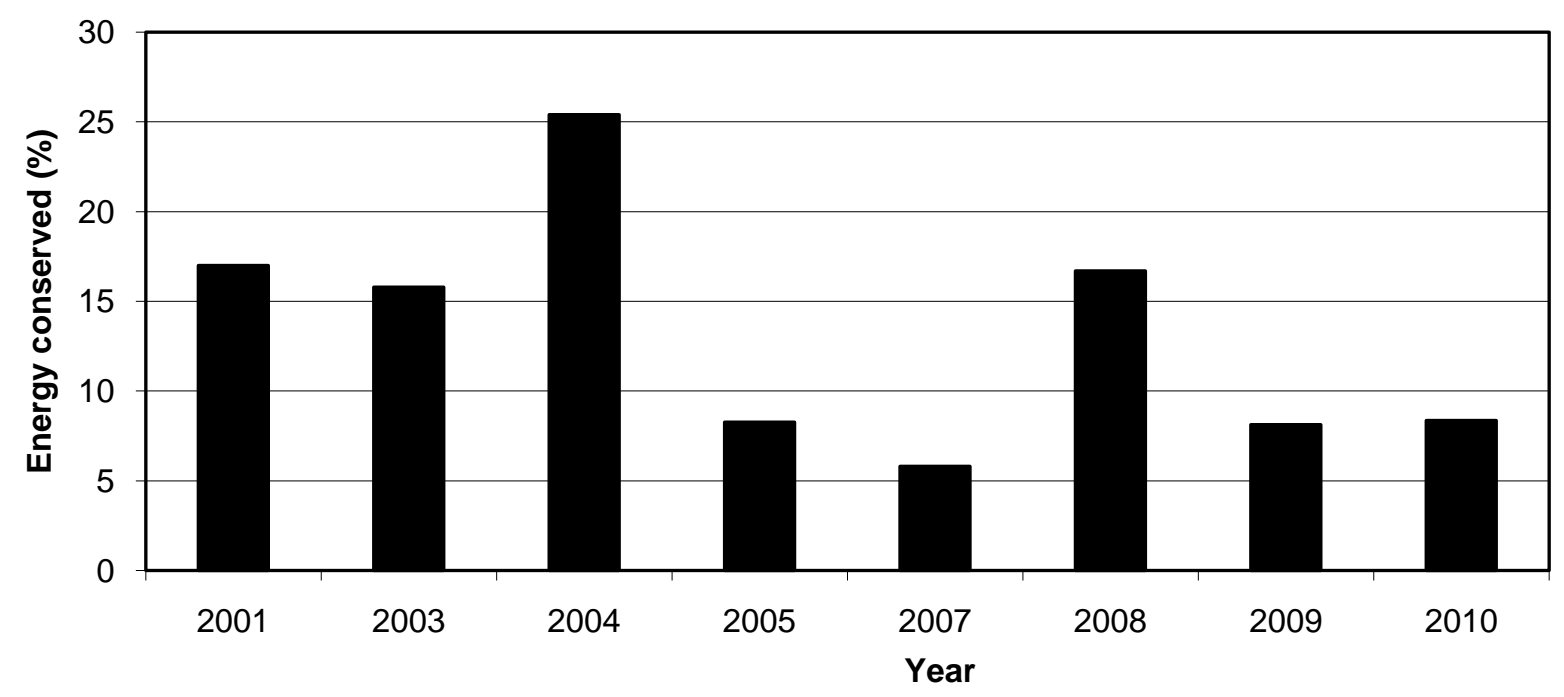

Figure 3. 5.-Average energy conserved if all recommendations are implemented.

It is noted that audit year 2004 has large energy conservation compared to other years. Upon closer examination of 2004 it was found that energy savings were achieved from the following recommendations: implementing a motor management system, replacing drive belts on large motors with energy efficient cog belts, and repairing compressed air leaks. If dividing the annual energy conserved in $\mathrm{kWh}$ by the annual 
production of lumber in MBF, it was found that the average energy conserved per MBF based on audit year was 8.5 , ranging from $3.24 \mathrm{kWh} / \mathrm{MBF}$ to $16.78 \mathrm{kWh} / \mathrm{MBF}$.

\subsection{Conclusions}

Energy consumption and efficiency are critical to hardwood sawmills due to economic conditions, energy prices, energy supply, and environmental related concerns. Survey responses from 58 sawmill in the Appalachian region revealed that the electricity consumed per month per mill averaged $107,007 \mathrm{kWh}$, and the average electric bill was $\$ 9,278$ per month. Based on the respondents who used natural gas, its consumption was 1,125 MCF per month per mill, and the average gas bill was $\$ 5,703$ per month per mill. Many opportunities exist for sawmills to reduce energy and waste costs in their lumber production. For example, potential energy savings could be achieved through efficient use of lighting, electrical motors, air compressors, and dry kilns. The energy utilization profile indicated that greater energy savings are possible through process changes and implementing new and more energy efficient technologies. If mills implement assessment recommendations, the energy conserved averaged $275,110 \mathrm{kWh}$ or $916 \mathrm{MMBtu}$. The average of carbon dioxide emission conserved was 587,045 lbs per mill per year. The average marginal cost for all energy audits was $\$ 17.87 / \mathrm{MMBtu}(\not 6.10 / \mathrm{kWh})$. The average processing cost was $\$ 10.04 / \mathrm{MBF}$ ranging from $\$ 0.81 / \mathrm{MBF}$ to $\$ 22.01 / \mathrm{MBF}$. Some assessment recommendations could be easily implemented for energy savings in mills, with little to no investment or very quick paybacks. These easy assessments include: turning off lights, changing to more energy efficient bulbs, reducing air compressor pressure, fixing compressed air leaks and switching to cog belts. 


\section{References}

Armstrong, J.P. and S.M. Brock.1989: Predicting fuel consumption of central Appalachian kilndrying enterprises. Forest Prod. J. 39(3):57-61.

Breiner, T., Quarles, S.L.; Huber, D. 1987. Steam and electrical consumption in a commercial scale lumber dry kiln. In: Proceedings, Western Dry Kiln Association; 1987 May 20.22;

Coeur d' Alene, ID. Corvallis, OR: Kozlik-Vandeventer, Inc.

Bond B. 2008. Sawmill \& Treating Insights: Rein in Escalating Energy

Costs.http://www.palletenterprise.com/articledatabase/view.asp? articleID=2648. Accessed May 1, 2011.

Chimack, M., C.E. Walker, and R. Miller. 2003. Energy conservation opportunities in the pulp and paper industry: an Illinois case study. ACEEE Summer Study Proceedings Paper.74-86

Denig, J., E. M. Wengert, W. T. Simpson. 2000. Drying hardwoods lumber Gen. Tech. Rep. FPL-GTR-118. USDA Forest Service, Forest Products Laboratory, Madison, WI.138 pp

Dillman, D.A. 2000. Mail and Internet Surveys: The Tailored Design Method. Second Edition. John Wiley and Sons, Inc. New York, NY. 464pp.

Dunning, S., and W. Todd. 1998. Energy and waste saving measures for the paper and wood products industry. IEEE Conference Record of Annual Pulp and Paper Industry Technical Conference, Jun 21-26, 1998, p.80-86.

Elliot, Brian. 2006. Compressed Air Operations Manual. Columbus, OH: McGraw-Hill Professional. P.407. 
Gopalakrishnan B., A. Mate, Y. Mardikar, D.P. Gupta, R.W. Plummer, and B. Anderson. 2005. Energy efficiency measures in the wood manufacturing industry. 2005 ACEEE Summer Study on Energy Efficiency in Industry, 68-76.

Hutchinson, V., L. Banata, and C. Hassler. 1998. Electricity billing and your wood production facility. Fact Sheet 17.Appalachian Hardwood Center.

http://ahc.caf.wvu.edu/joomla/index.php?option=com_remository\&Itemid $=148 \&$ func $=$ fileinf o\&id=146. Accessed May 1, 2011.

Li, J., M. McCurdy, and S. Pang.2006. Energy demand in wood processing plants. New Zealand Journal of Forestry, 51(2):13-18.

Luppold, W.G. 1995. Effect of the hardwood resource on the sawmill industry in the central and Appalachian regions. In: Gottschalk, Kurt W.; Fosbroke, Sandra L. C., ed. Proceedings, 10th Central Hardwood Forest Conference, Morgantown, WV. Gen. Tech. Rep: 481-487.

Luppold, W. G. 2009. The North American Hardwood Market: Past, Present, and Future. http://www.fcba.fr/ischp/ischp.ca/FR/pdf/1_comsession1/Luppold_northamerican.pdf. Accessed May 1, 2011.

Mardikar Y. 2007. Establishing baseline electrical energy consumption in wood processing sawmills: A model based on energy analysis and diagnostics. Ph.D. Dissertation. West Virginia University. Morgantown, WV.

Mate, A. 2002. Energy Analysis and Diagnostics in Wood Manufacturing Industry. Master Thesis. West Virginia University, Morgantown, West Virginia.

National Hardwood Lumber Association (NHLA). 2008. Membership directory. NHLA, Memphis, Tennessee. 
Oregon Department of Energy. 2007. Top Five Natural Energy Savings Opportunities in Six Industry Sectors. http://www.oregon.gov/ENERGY/CONS/Industry/topfivegassavings.shtml. Accessed: May 2, 2011.

Parhizkar, O., R.L. Smith, C. Miller. 2009. Comparison of important competitiveness factors for small-to medium- sized forest enterprises. Forest Prod. J. 59(5), 81-86.

Poole A. and P. Pinheiro. 2003. Developing Energy Profiles for Sawmills in the Amazon Region First Field Visit to Rondolândia and Ji-Paraná.

http://www.inee.org.br/down_loads/biomassa/AmazonSawmill.pdf\#search=\%22energy\%20profi ling\%20of\%20sawmill\%22. Accessed May 1, 2011.

Simpson, W.T. 1991. Dry kiln operators manual. Agric. Handbook. 188. Madison, WI: U.S. Department of Agriculture, Forest Service, Forest Products Laboratory. 274 p.

U.S. Department of Energy. 2008. http://www1.eere.energy.gov/industry/saveenergynow/index.html. Accessed May 1, 2011.

Wang, J., J. Wu, D. DeVallance, and J. Armstrong. 2010. Appalachian hardwood product exports - An analysis of the current Chinese market. Forest Prod. J. 60(1): 94-99.

Wengert, G. and D.Meyer.1992. Energy at the sawmill: conservation and cost reduction. Forestry Facts No. 61, 1992, Website as on January 2007, http://forest.wisc.edu/extension/publications/61.pdf .Accessed May 1, 2011. 


\section{CHAPTER 4: SUMMARY}

Changes in the Appalachian sawmills since the economic downturn were assessed in terms of employment, operating hours, production volume, wood residue production, log inventory, breakeven and losing money, and marketing and exporting strategies. The state of energy efficiency in Appalachian sawmills was examined, specifically in West Virginia. Most Appalachian sawmills have experienced significant changes in all aspects of the business. Changes in the industry included a drastic decrease in employees 29 percent followed by a decrease in production of 26 percent; while operating hours decreased an average of 9 percent industry wide.

The regional sawmill industry varied substantially among states, years in business and different production levels. For example, the state of Ohio did not experience that much of a change from 2008 versus 2010 based on our survey. However, West Virginia was one of the hardest hit states due to the economic downturn. Our findings also revealed that sawmills that have been in business for a short time are more unsteady because of their capability to handle the tough economic situations. Sawmills with higher production experienced a greater drop in operating hours; while the greatest decrease in production was found among sawmills with a low production level.

Log inventory in the Appalachian sawmills averaged just six weeks in 2010. Many mill managers were afraid of having too much inventory. Owners currently fear tying up excess capital in inventory or the market value changing drastically while the logs wait to be sawn. These fears can often lead to mills running out of logs during periods of bad weather. Since management of $\log$ inventory is critical to running a profitable sawmill in these turbulent 
economic times, it is important that managers could take appropriate actions to optimally balance $\log$ inventory.

Residue production averaged 139 tons for chips a week and 81 tons of sawdust per week. The survey revealed that many owners did not have special markets for their residue. Sawmill owners need to start considering residue as a value added product instead of waste from sawing logs into lumber. This change could net owners extra profit during the economic hardship.

Most Appalachian sawmills (67\%) have changed some marketing strategies since the economic downturn. Mill owners need to expand their marketing budgets to obtain new customers and figure out ways to differentiate their products from their competitors to create niche markets for their products. The delineation between competitors' products can help bring a higher price and more stability to markets. The market for hardwood lumber is very dynamic and changes weekly. This requires mill managers to actively search for the newest high profit market. Hardwood sawmills also need to develop better relationships with their consumers to get repeat, dependable customers.

Exporting is a weak point evident in many Appalachian sawmills, especially with smaller sawmills. Smaller mills often just sell their products to a middle man who then exports the products. This process results in a substantial loss in profit to sawmill owners. The survey revealed that many Appalachian sawmills feared exporting because of payment and transportation methods. Forty-three percent of survey respondents stated that they export products. Sawmills that currently do not export should consider exporting to achieve additional profits. The globalized economy requires exporting of products to maximize profit margins. In addition attention needs to be paid to other aspects of the business such as energy efficiency. 
Energy efficiency can be easily overlooked by sawmill operators. This has led to an oversight on management's part in needlessly wasting money. "A lack of corporate knowledge at sawmills has led to excessive operating costs and the consequent erosion of the market share in a globally competitive market" (Mardikar 2007). Energy upgrades were kept to a minimum in 2010 because of sluggish economy. Another problem mills were facing during the downturn included a lack of capital to make large upgrades to their mills. This study identified that larger sawmills were more likely to be energy efficient. For example, substantial utility savings can become a reality if old motors are upgraded to new energy efficient models instead of being rewound several times after failing. Energy efficient motors typically cost more to purchase; but, the payback point is typically short term, less than 5 years, because of the electricity that is saved during operating the motor (California Energy Commission 2000). Some mill owners do not invest money in more energy efficient motors because it is much cheaper to purchase a rewound motor. Electricity savings can easily be overlooked when comparing prices of electric motors. The high initial cost of being energy efficient in sawmills could scare off many business owners. Once the energy facts are clearly presented to mill managers and owners about higher efficiency equipment, the transition to energy efficient equipment should be more easily attained.

Sawmill survey respondents in the Appalachian region revealed average electrical consumption per month was $107,007 \mathrm{kWh}$, corresponding to an average electric bill of $\$ 9,278$. The sawmills that used natural gas reported average consumption per month to be 1,125 MCF with a corresponding bill of $\$ 5,703$. Sawmills could substantially reduce utility bills by becoming more energy efficient. Upgrades to electric motors, lighting, air compressors and dry kilns can result in substantial energy savings. If mills implemented all assessment recommendations of energy audits, the energy conserved could average 916 MMBtu 
or $275,110 \mathrm{kWh}$ per year. The average carbon dioxide emission conserved would be 587,045 lbs per mill per year. The average marginal cost was $\$ 17.87 / \mathrm{MMBtu}(\not 6.10 / \mathrm{kWh})$. The average processing cost was $\$ 10.04 / \mathrm{MBF}$ ranging from $\$ 0.81 / \mathrm{MBF}$ to $\$ 22.01 / \mathrm{MBF}$. Some assessment recommendations could be easily implemented for energy savings, with very little investment and quick payback period.

There are additional measures the mill could take for energy and cost effectiveness. For example, newer screw-drive air compressors typically have a throttling device that controls the amount of air getting compressed at any given time compared to the amount of air needed. This critical energy saving feature helps increase compressor efficiency. Increased energy savings can also be gained by checking for air leaks in the mill's air handling system. Air leaks are typically overlooked because air is "free", when in reality air leaks can cost sawmills thousands of dollars a year. Industry estimates predict that typically $25 \%$ to $40 \%$ of compressed air is lost through air leaks (Elliot 2006).

Historically sawmills have been reluctant to change, thus hindering their ability to maximize profits while providing customer satisfaction. The economic downturn caused a drastic decrease in production and employment. Many sawmills have changed some management and marketing strategies since the economic downturn. Appropriate policies and outreach education should be promoted to assist the regional sawmills, specifically smaller mills, to overcome the difficult economic times. 


\section{References}

California Energy Commission. Energy efficient motors. 2000, November 14. Retrieved from http://www.energy.ca.gov/process/pubs/motors.pdf

Elliot, B. 2006. Compressed Air Operations Manual. Columbus, OH: McGraw-Hill Professional. $407 \mathrm{pp}$.

Mardikar Y. 2007. Establishing baseline electrical energy consumption in wood processing sawmills: A model based on energy analysis and diagnostics. Ph.D. Dissertation. West Virginia University. Morgantown, WV. 